\title{
Saharan dust events in the European Alps: role in snowmelt and geochemical characterization
}

\author{
Biagio Di Mauro ${ }^{1}$, Roberto Garzonio ${ }^{1}$, Micol Rossini ${ }^{1}$, Gianluca Filippa ${ }^{2}$, Paolo Pogliotti ${ }^{2}$, Marta Galvagno ${ }^{2}$, \\ Umberto Morra di Cella $^{2}$, Mirco Migliavacca ${ }^{3}$, Giovanni Baccolo ${ }^{1,4}$, Massimiliano Clemenza ${ }^{4,5}$, Barbara Delmonte ${ }^{1}$, \\ Valter Maggi ${ }^{1}$, Marie Dumont ${ }^{6}$, François Tuzet ${ }^{6,7}$, Matthieu Lafaysse ${ }^{6}$, Samuel Morin $^{6}$, Edoardo Cremonese $^{2}$, and \\ Roberto Colombo ${ }^{1}$ \\ ${ }^{1}$ Earth and Environmental Sciences Department, University of Milano-Bicocca, 20126 Milan, Italy \\ ${ }^{2}$ Environmental Protection Agency of Aosta Valley, Aosta, Italy \\ ${ }^{3}$ Max Planck Institute for Biogeochemistry, Jena, Germany \\ ${ }^{4}$ National Institute of Nuclear Physics (INFN), University of Milano-Bicocca, 20126 Milan, Italy \\ ${ }^{5}$ Department of Physics “Giuseppe Occhialini”, University of Milano-Bicocca, 20126 Milan, Italy \\ ${ }^{6}$ Université Grenoble Alpes, Université de Toulouse, Météo-France, CNRS, CNRM, Centre d'Etudes de la Neige, \\ Grenoble, France \\ ${ }^{7}$ UGA/CNRS, Institut des Géosciences de l'Environnement (IGE), Saint Martin d'Hères, France
}

Correspondence: Biagio Di Mauro (biagio.dimauro@unimib.it)

Received: 7 November 2018 - Discussion started: 15 November 2018

Revised: 5 March 2019 - Accepted: 19 March 2019 - Published: 8 April 2019

\begin{abstract}
The input of mineral dust from arid regions impacts snow optical properties. The induced albedo reduction generally alters the melting dynamics of the snowpack, resulting in earlier snowmelt. In this paper, we evaluate the impact of dust depositions on the melting dynamics of snowpack at a high-elevation site $(2160 \mathrm{~m})$ in the European Alps (Torgnon, Aosta Valley, Italy) during three hydrological years (2013-2016). These years were characterized by several Saharan dust events that deposited significant amounts of mineral dust in the European Alps. We quantify the shortening of the snow season due to dust deposition by comparing observed snow depths and those simulated with the Crocus model accounting, or not, for the impact of impurities. The model was run and tested using meteorological data from an automated weather station. We propose the use of repeated digital images for tracking dust deposition and resurfacing in the snowpack. The good agreement between model prediction and digital images allowed us to propose the use of an RGB index (i.e. snow darkening index - SDI) for monitoring dust on snow using images from a digital camera. We also present a geochemical characterization of dust reaching the Alpine chain during spring in 2014. Elements found in dust were classified as a function of their
\end{abstract}

origin and compared with Saharan sources. A strong enrichment in Fe was observed in snow containing Saharan dust. In our case study, the comparison between modelling results and observations showed that impurities deposited in snow anticipated the disappearance of snow up to $38 \mathrm{~d}$ a out of a total 7 months of typical snow duration. This happened for the season 2015-2016 that was characterized by a strong dust deposition event. During the other seasons considered here (2013-2014 and 2014-2015), the snow melt-out date was 18 and $11 \mathrm{~d}$ earlier, respectively. We conclude that the effect of the Saharan dust is expected to reduce snow cover duration through the snow-albedo feedback. This process is known to have a series of further hydrological and phenological feedback effects that should be characterized in future research.

\section{Introduction}

Mineral dust (hereafter referred as dust) plays an important role in Earth's climate and in biogeochemical cycles (Mahowald et al., 2010, 2013; Thornton et al., 2009). It provides nutrients such as iron, nitrogen, and phosphorous to marine and terrestrial ecosystems (Aciego et al., 2017; Jickells, 
2005; Yu et al., 2015), and it influences the shortwave radiation balance of the atmosphere (Ginoux, 2017; Mahowald et al., 2013). Because of its peculiar optical properties, dust efficiently scatters incoming solar radiation and exerts a direct climate forcing in the atmosphere (Tegen and Lacis, 1996). As a function of key variables (e.g. imaginary part of the refractive index, height of the dust layer, dust particle size, and dust optical depth), the net radiative forcing of dust can be either negative or positive at the top of the atmosphere (Liao and Seinfeld, 1998; Tegen et al., 1996), representing a significant uncertainty in current climate models (Potenza et al., 2016). The main sources of dust are arid and hyperarid regions of the planet. Under specific atmospheric conditions, fine and coarse particles of dust can be suspended in the troposphere, generating characteristic dust storms (Francis et al., 2018; Goudie and Middleton, 2001). Finer dust $(<5 \mu \mathrm{m})$ has a prolonged atmospheric lifetime, of the order of days, allowing for its long-range transport (Mahowald et al., 2013; Tegen and Lacis, 1996). When dust is deposited on snow- and ice-covered regions, its radiative impact at the surface results in a positive radiative forcing (Painter et al., 2012; Skiles et al., 2018). Snow optical properties largely depend on its microstructure and on the presence of impurities (also referred as light-absorbing particles - LAPs), such as carbonaceous or mineral particles (Warren and Wiscombe, 1980). Indeed, dust lowers the snow albedo in the visible wavelengths, enhancing the absorption of solar radiation (Di Mauro et al., 2015; Painter et al., 2007) and thus triggering the snow-albedo feedback (Hansen and Nazarenko, 2004). The alterations of the optical properties of snow are known to accelerate the melting processes (Drake, 1981; Painter et al., 2012). First estimations of the impact of dust on snow date back to the beginning of the last century; Jones (1913) estimated 1 month of earlier snowmelt due to dust deposition in the US. Drake (1981) estimated $4 \mathrm{~d}$ of advancement in the snowmelt.

The impact of dust on snow melting has been largely investigated in the western US, where both radiative and hydrological effects have been assessed using aerial, satellite, and automatic weather station (AWS) data (Painter et al., 2012a, b, 2013a, 2018; Reynolds et al., 2013; Skiles et al., 2012). In this area, the proximity of arid regions to the mountain ranges determines massive dust depositions on snowcovered mountain ranges. Dust depositions caused an earlier snowmelt that ranged from $35 \mathrm{~d}$ (Painter et al., 2007) to a maximum of $51 \mathrm{~d}$ (Skiles et al., 2012), strongly impacting water supplies around the area (Painter et al., 2012, 2018). Increases in dust deposition have been recently observed in this area, and they were linked to human activity and climate change (Neff et al., 2008). Other studies, conducted in Iceland (Dagsson-Waldhauserova et al., 2015; Wittmann et al., 2017), in the Himalayas (Gautam et al., 2013), in Norway (Matt et al., 2018), and in the European Alps (Dumont et al., 2017; Di Mauro et al., 2015; Tuzet et al., 2017; Greilinger et al., 2018) reported significant impacts of dust on snow opti- cal properties and snowpack dynamics. Impacts on glaciers optical properties and mass balance were also reported in the literature (Gabbi et al., 2015; Di Mauro et al., 2017; Oerlemans et al., 2009).

The composition of dust varies as a function of its origin (Krueger et al., 2004) and timing (Kumar et al., 2018), with an effect on its optical properties (Caponi et al., 2017). Lawrence et al. (2010) presented a comprehensive characterization of the mineralogical and geochemical properties of dust deposited from the atmosphere in the San Juan Mountains (Colorado, US). In this area, dust is dominated by silt and clay particles, indicating a regional source area. In the European Alps, a large fraction of dust reaching high mountains and glaciers originate from the Sahara (Haeberli, 1977; Kandler et al., 2007; Krueger et al., 2004; Schwikowski et al., 1995; Thevenon et al., 2009), but inputs from local sources cannot be excluded. Even though the Alps are located at a distance of about $3000 \mathrm{~km}$ from the largest desert of the planet, they are frequently affected by dust depositions. Due to their considerable elevation, the Alps act as an orographic barrier, enhancing cloud formation, precipitation, and hence dust scavenging from the atmosphere to the ground (De Angelis and Gaudichet, 1991; Prodi and Fea, 1979). Dust deposition in the Alps is a well-known process, and its frequency is studied using ice cores from mountain glaciers (De Angelis and Gaudichet, 1991; Thevenon et al., 2009). Each year, the Sahara provides up to 760 million tons of dust to the atmosphere (Callot et al., 2000). Dust reaching Europe is dominated by silicates and aluminium oxide (Goudie and Middleton, 2001); other contributions come from quartz, calcium-rich particles, sulfates, hematite, and soot (Kandler et al., 2007). The optical properties of particles are directly related to dust composition (Linke et al., 2006), and hence the latter is expected to modify the dust radiative effect on snow (Reynolds et al., 2013).

Saharan dust can provide nutrients to many alpine ecosystems (Field et al., 2010; Okin et al., 2004). Aciego et al. (2017) recently showed that dust transported from Asia to the western US provides nutrients to montane forest ecosystems. This aspect has never been evaluated for mountain ecosystems in the European Alps, where dust may compete with fine debris from local rocks in providing nutrients to soils. Conversely, the direct deposition of dust on plants can limit the photosynthetic capacity (Neves et al., 2009). Steltzer et al. (2009) reported results from a manipulation experiment conducted in the western US to study the dependence of vegetation phenology on snowmelt. They measured an advancement of $7 \mathrm{~d}$ in snowmelt when dust was manually added to the snowpack. This process can simulate a dry deposition from the atmosphere. In the Alps, most dust depositions occur by wet deposition (mainly snowfalls; Sodemann et al., 2006), so dust is expected to be included within ice grains. Flanner et al. (2012) showed that when black carbon is internally mixed in ice grains, its radiative effect is stronger. If this also holds true for dust, wet deposition of 
dust may exert a stronger effect with respect to dry depositions. Shifts in vegetation phenology also affect the timing of migration, breeding, and asynchronies between interacting animal species (Cohen et al., 2018; Thackeray et al., 2016). Dust-induced snowmelt can anticipate the beginning of the growing season, and this can result in an earlier start of the seasonal cycle of both animals and plants. Changes in snowfalls and dust depositions are likely to occur more frequently in a warming climate. At the moment, the impact of Saharan dust events on the biogeochemistry of ecosystems in the European Alps has been poorly analysed (Avila and Peñuelas, 1999).

Seasonal snow represents an important reservoir of fresh water in mountain ranges and polar regions. Recent climate changes showed that this exerts a strong impact on the duration of snow cover (Vaughan et al., 2013), in particular in the European Alps (Beniston, 2005; Beniston et al., 2018). It has been observed that, especially in spring, snow cover extent has decreased in the Northern Hemisphere (Brown and Robinson, 2011; Brown et al., 2009). Earlier snowmelt can have an impact on vegetation phenology (Steltzer et al., 2009) and water availability (Beniston et al., 2003), and it is expected to alter hydrologic regimes in the future. Accelerated snowmelt due to dust can alter also surface hydrology in large mountain chains like the European Alps. In the Po Plain, for example, the most important renewable energy source is represented by hydropower. Meltwater from seasonal snow is a fundamental resource for agriculture during spring and summer (Huss et al., 2017).

In this paper, we quantitatively estimate the impact of dust from the Sahara on snow dynamics. As a test area, we use the experimental site in Torgnon (Aosta Valley, western Italian Alps) equipped with several sensors for measuring snow properties. Snow dynamics were simulated with a multilayer, physically based energy balance model (Crocus, Vionnet et al., 2012), which can incorporate the effect of LAPs (mineral dust and black carbon) in snow and estimate their impact on snowmelt (Tuzet et al., 2017). The timing and intensity of Saharan dust depositions were simulated using two independent models (ALADIN-Climate and NMMB/BSCDust). Observed and simulated snow variables are compared, and the role of impurities on snowmelt is discussed. We also made use of repeated images from a digital camera to track the deposition and resurfacing of impurities. Finally, we present a geochemical characterization of dust reaching the Alps, and thus we discuss the possible biogeochemical and hydrological role of dust in the Alps.

\section{Data and methods}

\subsection{Torgnon experimental site}

The study area is located in the north-western Italian Alps (Aosta Valley, Italy) at an elevation of $2160 \mathrm{~m}$ a.s.l. $\left(45^{\circ} 50^{\prime} 40^{\prime \prime} \mathrm{N}, 7^{\circ} 34^{\prime} 41^{\prime \prime} \mathrm{E}\right)$. The experimental site belongs to the Phenocam (Torgnon-nd, https://phenocam.sr.unh. edu/webcam/, last access: 2 April 2019), ICOS (IT-Tor; https://www.icos-ri.eu/, last access: 2 April 2019), and LTER (lter_eu_it_077; https://deims.org/site, last access: 2 April 2019) networks. The area is a subalpine unmanaged pasture classified as intra-alpine with a semi-continental climate. The site is generally covered by snow from the end of October to late May. Further information regarding the site can be found in Galvagno et al. (2013). An AWS was installed in 2009 at the experimental site of Torgnon. Air temperature is measured by a HMP45 (Vaisala Inc.); snow depth is measured with a SR50A sonic sensor (Campbell Scientific, Inc.). Albedo is measured with a Kipp \& Zonen CNR4 net radiometer. The snow water equivalent (SWE) is measured with a gamma monitor (GMON; Campbell Scientific, Inc.) sensor. Solid and liquid precipitations were measured with a Pluvio2 OTT instrument. Wind speed and direction were measured with a CSAT3 three-dimensional sonic anemometer (Campbell Scientific, Inc.). Data are available at hourly time resolution.

\subsection{Digital image analysis}

In recent years, digital images analysis was applied to monitor vegetation phenology (Julitta et al., 2014; Migliavacca et al., 2011; Richardson et al., 2007), landslides, glaciers (Jung et al., 2010), and snow (Corripio, 2004; Dumont et al., 2011; Hinkler et al., 2002; Parajka et al., 2012). Regarding the latter two, snow albedo and snow cover were successfully estimated using digital cameras in alpine areas. For this study, digital RGB images were collected using a Nikon digital camera (model d5000, also referred as "Phenocam") installed at the experimental site in 2013 in the vicinity of the AWS. Following Richardson et al. (2007), the camera was pointed north and set at an angle of about $20^{\circ}$ below horizontal. The camera focal length is $33 \mathrm{~mm}$, and the field of view is $79.8^{\circ}$. The camera was fixed at $2.5 \mathrm{~m}$ above the ground, and the same scene was repeatedly photographed. Digital images were collected in the Joint Photographic Experts Group (JPEG) format with a resolution of 12 megapixels and threecolour channels (namely red, green, and blue) featuring eight bits of radiometric resolution. The images were collected from 10:00 to 17:00 LT (local time: UTC+1), with an hourly temporal resolution. Exposure mode and white balance were set to automatic.

A region of interest (ROI) was firstly identified in an approximately flat area to analyse snow evolution. Images were acquired during the hydrological years 2013-2016. Red, green, and blue chromatic coordinates were extracted from the selected ROI using the Phenopix R package (Filippa et al., 2016). Then, the snow darkening index (SDI; Di Mauro et al., 2015) was calculated from a red and green digital numbers (DNs) as follows: 


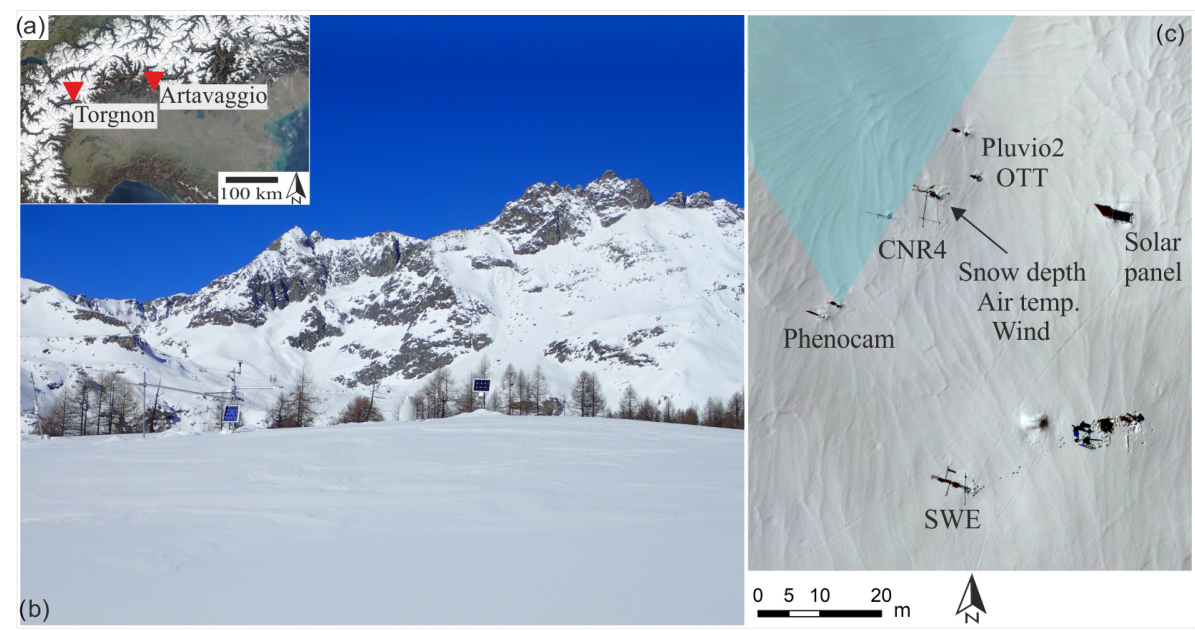

Figure 1. (a) Location of Torgnon (Aosta) and Artavaggio plains (Lecco) in the European Alps. (b) A picture of the experimental site of Torgnon (2160 m a.s.1.). (c) Aerial view of the site in Torgnon with the location of different instruments installed. The field of view of the Phenocam is represented with a blue shaded area.

$\mathrm{SDI}=\frac{\mathrm{DN}_{\text {Red }}-\mathrm{DN}_{\mathrm{Green}}}{\mathrm{DN}_{\text {Red }}+\mathrm{DN}_{\text {Green }}}$

The SDI was correlated with the concentration of dust in snow (Di Mauro et al., 2015) and was used to represent the spatial distribution of impurities from space (Ganey et al., 2017; Di Mauro et al., 2017) and from hyperspectral images of ice cores (Garzonio et al., 2018). The SDI calculated from RGB data collected from an unmanned aerial vehicle (UAV) was found to be correlated with the SDI calculated from field spectroscopy data (Di Mauro et al., 2015). This motivated the idea to monitor dust deposition and resurfacing dynamics using repeated digital images from the camera installed in Torgnon. In this work, the SDI was calculated for each available image, then a daily average was calculated. Days with an SDI $>0$ were considered to be markers of the presence of dust on snow.

\subsection{Snowpack modelling}

Snow dynamics in Torgnon were simulated using the SURFEX and ISBA-Crocus model, hereinafter referred as Crocus. Crocus is a snow model initially developed for avalanche forecasting and used for hydrological estimation as well as numerical prediction (Brun et al., 1989). Crocus is a onedimensional multilayer model that simulates the evolution of the snowpack based on input meteorological driving conditions (Brun et al., 1989, 1992). Snow dynamics are represented as a function of energy and mass transfer within the snowpack, between both the snowpack and the atmosphere, and the snowpack and the ground below (Vionnet et al., 2012). In this study, we used a specific Crocus version using the Two-stream Analytical Radiative TransfEr in Snow (TARTES) radiative transfer model (Libois et al., 2013) to obtain simulations of snow spectral albedo as a function of snow properties, LAP concentrations, and LAP optical properties. The TARTES model is based on the asymptotic approximation of the radiative transfer theory (AART; Kokhanovsky and Zege, 2004) and accounts for the effect of snow microstructure and impurities, such as dust and black carbon. The snow spectral albedo simulated with TARTES was used to calculate the SDI (using the formulation proposed in Di Mauro et al., 2015), and it was compared with the SDI calculated from the digital camera. A complete description of this specific Crocus model version can be found in Tuzet et al. (2017). Crocus is embedded in the SURFEX surface scheme and is permanently coupled with the ISBADIF soil model.

Variables needed for running Crocus simulations are the following: air temperature, direct and diffuse shortwave incoming radiation, longwave radiation, wind speed and direction, specific humidity, surface pressure, and solid and liquid precipitation. The model was forced using meteorological data from the station in Torgnon for the seasons 2013 and 2016 at an hourly time step. All variables were measured at the station of Torgnon, except for diffuse shortwave incoming radiation, which was measured (with a BF3 sensor; Delta-T Devices Ltd., Cambridge, UK) in another station located $2 \mathrm{~km}$ from Torgnon. The instrument used for precipitation measurements (Pluvio2 OTT) does not feature a windshield. This can be problematic, since underestimations of snowfall can occur during intense wind events. For this reason, we corrected the data following the prescriptions proposed in Kochendorfer et al. (2017). Some manual adjustments to solid precipitations were needed in the case of strong wind events. In addition to the abovementioned meteorological data, the Crocus version of Tuzet et al. (2017) needs dust and black carbon deposition fluxes. 
In this study, these fluxes were taken from the atmospheric model ALADIN-Climate (Nabat et al., 2015). For evaluating the impact of dust depositions on the snowpack dynamics, key variables (e.g. albedo, snow depth, and snow water equivalent) measured from the AWS were compared with Crocus simulations with and without impurities (dust and black carbon) in snow. In addition, soil temperature was initialized using a spin-up simulation of 4 years.

\subsection{Dust concentration, size distribution, and geochemistry}

On 6 April 2016, a field campaign was organized to collect snow samples at the experimental site of Torgnon. Six snow pits were dug in different locations placed a few metres away from the AWS. For each snow pit, we collected a surface sample at $0 \mathrm{~cm}$ and three samples at depths equal to 20,40 , and $60 \mathrm{~cm}$ from the surface. Samples were collected using sterilized Corning tubes $(50 \mathrm{~mL})$ and kept frozen until measurements. Dust concentration and size distribution were measured using a Coulter counter technique. Samples were melted in a clean room (class 1000 clean room at EuroCold Laboratory Facilities, University of Milano-Bicocca) and analysed with a Multisizer ${ }^{\mathrm{TM}} 4 \mathrm{e}$ COULTER COUNTER ${ }^{\circledR}$. The instrument was set with a $100 \mu \mathrm{m}$ orifice, allowing for the detection of particles with a diameter (equivalent spherical) between 2 and $60 \mu \mathrm{m}$, divided into 400 size channels. To obtain dust mass from particle volume, a crustal density of $2.5 \mathrm{~g} \mathrm{~cm}^{-3}$ was adopted. Total dust concentration was calculated considering the integral of the concentration between 2 and $60 \mu \mathrm{m}$. Details about the technique can be found in Ruth et al. (2008).

In addition, dust samples collected in the Alps at $150 \mathrm{~km}$ from Torgnon (Artavaggio, Lecco, Italy, $1650 \mathrm{~m}$ a.s.l.) in March 2014 are used here to characterize the bulk composition of dust events and the elemental input to alpine ecosystems. Snow samples were transported before melting in a cold facility, where they were stored until the preparation for the successive analyses. At first, they were melted, and an aliquot $(5-10 \mathrm{~mL})$ was measured through Coulter counter technique (CC) for the determination of dust size distribution. These data were already published (Di Mauro et al., 2015). A second aliquot consisting in few millilitres of melted snow was dedicated to instrumental neutron activation analysis (INAA) for the analysis of elemental composition (Greenberg et al., 2011). To this aim, dust was extracted and separated using a filtration system equipped with polycarbonate membranes (pore size $0.4 \mu \mathrm{m}$, well below the typical volume mode grain size of Saharan dust deposited on the Alps). Two distinct samples were prepared. One sample (SH1) was extracted from the reddish snow corresponding to the snow deposited during the Saharan event; it consisted of $7.2 \pm 0.2 \mathrm{mg}$ of dust. A second sample (SH2) was prepared for comparison, filtering clean white snow. In this case, given the low concentration of impurities, it was possible to retrieve $202 \pm 11 \mu \mathrm{g}$ of particulate matter. For both samples, in addition to absolute concentration (mass fraction), normalized ones were also calculated. The average upper continental crust composition (UCC; Rudnick and Gao, 2003) was selected as a normalizing reference to highlight the influence played by crust-derived material and the possible role of non-crustal sources for specific elements. Neutron irradiation was performed at the LENA laboratories at the University of Pavia (Borio di Tigliole et al., 2010), where a TRIGA Mark II research nuclear reactor is installed $(250 \mathrm{~kW})$. Activated samples were successively analysed using high-purity germanium detector available at the Radioactivity laboratory of the Milano-Bicocca University. Two irradiations and several acquisitions of the $\gamma$ spectra were necessary to detect the largest number of radionuclides, ranging from the short-lived species to the long-lived ones. For a complete description of the method, including the estimation of errors, see Baccolo et al. $(2015,2016)$.

\subsection{Dust transport and deposition modelling}

In addition to the ALADIN-Climate model, dust transport and deposition were monitored using the NMMB/BSC-Dust model. This is an online multi-scale atmospheric dust model (Pérez et al., 2011); it was used here to provide dust forecasts from the Sahara to the European Alps. NMMB/BSCDust provides both atmospheric concentration and deposition fluxes of dust with a $0.3^{\circ} \times 0.3^{\circ}$ horizontal resolution. During the three seasons considered here, we classified dust events as "strong" events with dust deposition fluxes larger than $800 \mathrm{mg} \mathrm{m}^{-2}$ and "weak" events with lower concentrations. The timings of the events simulated with the NMMB/BSC-Dust model were qualitatively compared to those simulated with the ALADIN-Climate model during the period analysed here (2013-2016).

\section{Results and discussion}

\subsection{Modelled dust deposition events}

The period between 2013 and 2016 was characterized by two strong events (dust fluxes $>800 \mathrm{mg} \mathrm{m}^{-2}$ ) and several weak events (dust fluxes $<800 \mathrm{mg} \mathrm{m}^{-2}$ ) distributed during the seasons. The strong events that occurred on February 2014 and on April 2016. The event of February 2014 was already analysed in the scientific literature (Di Mauro et al., 2015; Tuzet et al., 2017; Dumont et al., 2017). The event of April 2016 lasted several days and transported a considerable dust amount to the western sector of the European Alps (Fig. 2; Greilinger et al., 2018). According to the NMMB/BSC-Dust model, during these two strong events, dust was primarily deposited in the Alpine chain by wet deposition. In Fig. 2, we show an example (5 April 2016) of the concentration of dust deposited according to NMMB/BSC-Dust and a longitudinal and latitudinal transect. NMMB/BSC-Dust predicted 

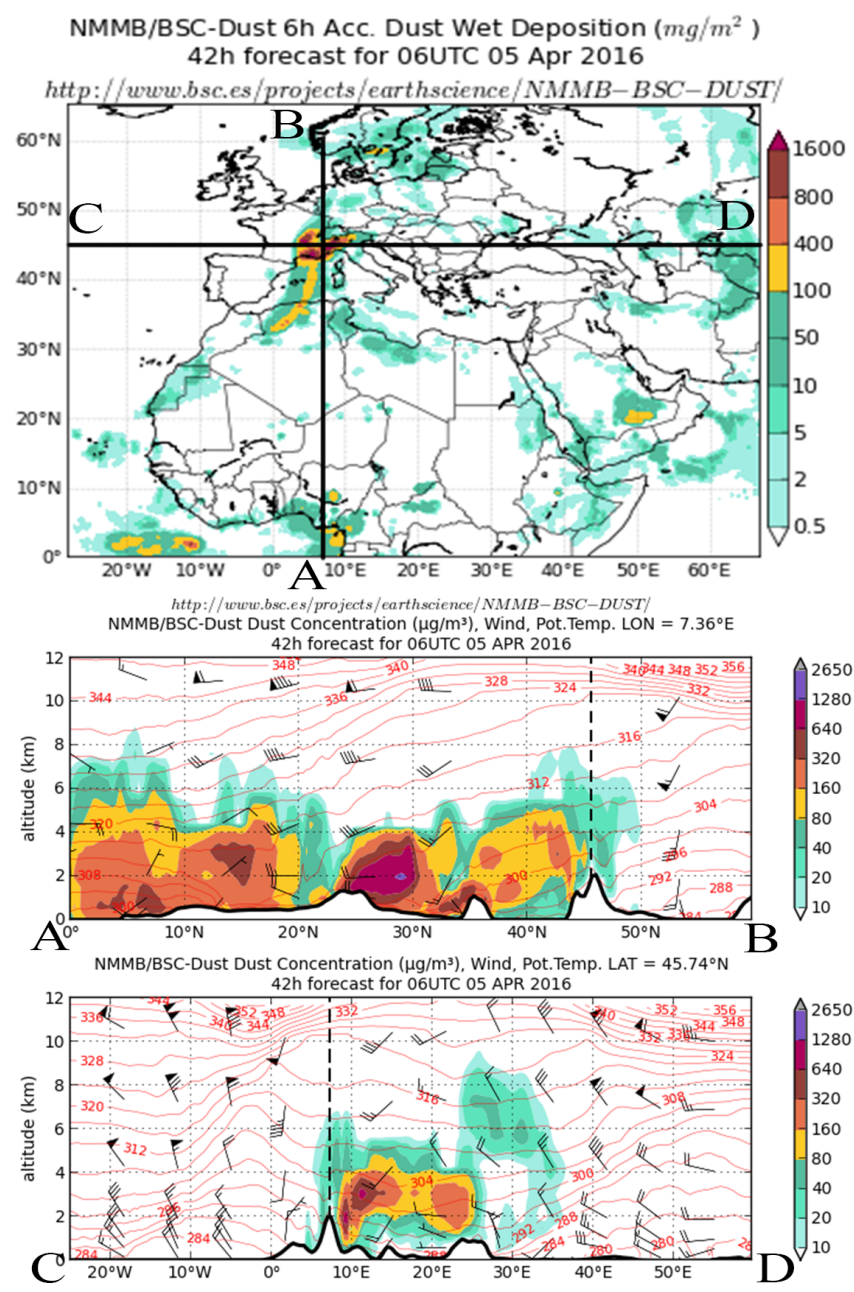

Figure 2. NMMB/BSC-Dust forecast for the event of April 2016. In the top panel is the estimated surface concentration by wet deposition. The lower panels represent, respectively, a latitudinal and longitudinal transect centred on the city of Aosta $\left(45.74^{\circ} \mathrm{N}\right.$; $7.36^{\circ} \mathrm{E}$ ). Images are from the NMMB/BSC-Dust model, operated by the Barcelona Supercomputing Center (http://www.bsc.es/ess/ bsc-dust-daily-forecast/, last access: 2 April 2019).

up to $1600 \mathrm{mg} \mathrm{m}^{-2}$ of dust deposition in the western Alps. In the latitudinal and longitudinal profiles, it is clearly visible that the plume reached almost $6 \mathrm{~km}$ in altitude. The highest concentrations in the atmosphere were reached in southern France and in the north-west of Italy. The experimental site of Torgnon is located in the Italian western Alps, and it represents a good candidate for analysing the effect of this strong dust event on snow dynamics.

\subsection{Observed and simulated snow dynamics}

In Fig. 3, a comparison of variables observed at the Torgnon station and simulated with the Crocus model using impurity fluxes is presented. We show time series of the snow albedo, SWE, and snow depth (SD). In general, the Crocus model represented snow dynamics well during the hydrological seasons 2013-2016. In Fig. 4, we present a quantitative comparison (coefficient of determination $-R^{2}-$ and root-mean-square error - RMSE) between snow variables observed and simulated, including and excluding the effect of LAPs. Crocus simulations accounting for the impact of LAPs showed a better agreement with observations than Crocus simulations that not account for the effect of LAPs. The snow albedo was underestimated from Crocus during the accumulation period (see Fig. 3a). Instead, during the melting period, the decreasing trend observed in snow albedo was reproduced well by the Crocus model accounting for the role of impurities. During the accumulation period, the albedo modelled by both Crocus simulations was always lower than the observed albedo. During the melting season, a clear divergence is observed between the Crocus simulation with LAPs and that without LAPs. Instead, the Crocus simulation with LAPs is more correlated with the observed snow depth. The observed and simulated SWE and snow depth show a large interannual variability. The SWE is strongly overestimated in the season 2013-2014; while during the accumulation period snow depth is represented well in the model, the melting rate is higher in the observed snow depth. This results in a delay of snow melt-out dates in both Crocus simulations (with and without impurities). A similar pattern in snow depth is also observed in the season 2014 2015. Unfortunately, the measured SWE was not available for this season. During the season 2015-2016, the correlation between the observed and simulated snow depth accounting for the impact of impurities was very high, both for snow depth $\left(R^{2}=0.96\right.$; RMSE $\left.=0.05 \mathrm{~m}\right)$ and the SWE $\left(R^{2}=0.97\right.$; RMSE $\left.=13 \mathrm{~mm}\right)$. The difference in snow meltout dates between observed and simulated data accounting for LAPs was 12,10 , and $11 \mathrm{~d}$, respectively, for the seasons 2013-2014, 2014-2015, and 2015-2016. Instead, the comparison between snow melt-out dates simulated with and without impurities was 18,11 , and $38 \mathrm{~d}$ for the seasons 2013 2014, 2014-2015, and 2015-2016, respectively. For snow depth (Fig. 4a) and the SWE (Fig. 4b), Crocus simulations with LAPs generally resulted in a lower RMSE and higher $R^{2}$ with respect to Crocus simulations without LAPs. Instead, for snow albedo (Fig. 4c), the resulting RMSE was smaller for Crocus simulations without LAPs. We underline that these RMSE values are associated with very low explained variance $\left(R^{2} \sim 0.2\right.$ for the seasons 2014-2015, 2015-2016, and all years, and $R^{2}=0.43$ for the season 2013-2014). Thus, Crocus simulations with LAPs perform better than Crocus simulations without LAPs in modelling snow dynamics at Torgnon. 
In Fig. 3d, we show also a qualitative comparison between the dust fluxes simulated with ALADIN-Climate and with the NMMB/BSC-Dust model. In general, a good agreement between the two models was observed. The two most intense events (February 2014 and April 2016) are identified by both models. Smaller events are also reproduced, whereas sometimes small events are seen only by ALADIN-Climate.

Once dust fluxes are deposited on the snowpack, they are buried by subsequent snowfalls. In Fig. 3e, we show the multilayer concentration of dust in snow simulated with Crocus. It is clear that dust is resurfacing towards the end of the season, when the snow albedo feedback intensifies and promotes the melting. The surface concentration of dust (average of the first $10 \mathrm{~cm}$ of snow) in the three seasons considered in this study show an important interannual variability (Fig. 3f). In fact, whereas the first two seasons show surface concentrations of dust lower than $150 \mu \mathrm{g} \mathrm{g}^{-1}$, the last season (20152016) shows concentrations up to $350 \mu \mathrm{g} \mathrm{g}^{-1}$ at the end of the season. This can be due to the longer duration of the dust event in April 2016 and may also explain the large change (38 d) in the snow melt-out dates observed in the data.

Results from samples collected in Torgnon showed that significant concentrations of dust were present in the snowpack in April 2016 (Fig. 5). It is interesting to note that the mode of the dust size distribution is $7.9 \mu \mathrm{m}$ for surface snow and $8.5 \mu \mathrm{m}$ for snow samples collected at 20 and $40 \mathrm{~cm}$ depth. Instead, dust particles found in snow at the bottom of the snowpack $(60 \mathrm{~cm}$ depth) feature a mode of $3.2 \mu \mathrm{m}$. This deeper layer can be probably due to the scavenging of small dust particles by meltwater or to other undetected processes. The first three distributions can be due to the weak depositions that happened in February and March and were then buried by new snow. Dust size distributions are compatible with other measurements of dust enclosed in snow and ice in the Alps (3-5 um; Maggi et al., 2006) and in the Caucasus (1.98-4.16 $\mu \mathrm{m}$; Kutuzov et al., 2013). Differences between our samples and these studies may be ascribed to the different elevation of the samplings. Samples shown in Fig. 5 feature a significant noise in the tail of the distribution. This can be ascribed to the aggregation of fine particles or to an input of local particles with larger diameters. A contribution of large particles of local origin cannot be excluded, and it may have a strong influence on snowmelt. At the moment, we do not have enough data to decouple the effect of large and small particles on the snow albedo. Total concentration of dust in Torgnon was estimated by adding up different channels from the size distributions. Among the six different snow profiles measured, surface concentrations reached a maximum of $65 \mu \mathrm{g}_{\text {dust }} \mathrm{g}_{\text {snow }}^{-1}$, with a mean of $45.6 \mu \mathrm{g}_{\text {dust }} \mathrm{g}_{\text {snow }}^{-1}$ and a standard deviation of $15.8 \mu g_{\text {dust }} g_{\text {snow }}^{-1}$.

Measurements of dust concentrations are available only for 6 April 2016. On this day, the dust concentration profile simulated by Crocus spans from 11 (bottom) to 108.7 (top) $\mu g_{\text {dust }} g_{\text {snow }}^{-1}$. Modelled and measured surface concentrations of dust showed some difference: $43.7 \mu \mathrm{g}_{\text {dust }} \mathrm{g}_{\text {snow }}^{-1}$ for the most concentrated surface sample and $65.1 \mu g_{\text {dust }} g_{\text {snow }}^{-1}$ for the mean of the six snow pits. This variability can be explained by the strong spatial mismatch between the spatial resolution of ALADIN-Climate model $(50 \mathrm{~km})$ and the point measurement of dust concentration. Differences can also depend on snow sampling, vertical resolution, and Crocus layer thickness. Model improvements are needed to downscale the spatial resolution of LAPs fluxes. The installation of a wet and dry sampler (e.g. deposimeter) at experimental sites may help to drive the Crocus model with measured deposition fluxes. It is important to notice that ALADIN-Climate predicted also depositions of black carbon. At the moment, we do not have measurements to validate this estimation, but the presence of black carbon in snow may have amplified the snow-albedo feedback in the snowpack. The role of black carbon in Alpine snow still represents a great uncertainty in snow modelling and climate prediction in the Alps. While the role of industrial black carbon on post-industrial glacier retreat has been debated (Painter et al., 2013b; Sigl et al., 2018), its role in seasonal snow melting has not been studied in the European Alps.

Hereafter we focus on the season 2015-2016, since Crocus simulations with impurities resulted in a $38 \mathrm{~d}$ advancement of the snow melt-out date compared to the corresponding simulations without impurities. This season was characterized by dust surface concentration in snow being almost double with respect to the other two seasons considered in this study (see Fig. 3f). In Fig. 6, we show the comparison of the snow depth simulated with Crocus, including and excluding the impact of impurities. During the season 2015-2016, about $1 \mathrm{~m}$ of snow was on the ground in Torgnon. The model without impurities predicted a longer duration of snow on the ground than the model with impurities. Two late snowfalls occurred in May, and this probably increased the difference between the simulations. Since air temperatures were still close to $0^{\circ}$ (data not shown), snow was preserved at the ground in the simulations without impurities, and this further prolonged the snow season duration. Considering that the first significant snowfalls occurred in January, the snow season was shortened by about $20 \%$ of the total because of impurities.

In Fig. 6, we plot the SDI calculated from the radiative transfer model (TARTES) included in Crocus (SDI-Crocus hereafter) and from the RGB camera (SDI-Phenocam hereafter). Regarding the digital camera data, days with SDI $>0$ are represented as shaded green bands. We observed an agreement between the two datasets. SDI-Crocus increased during April. In particular, at the beginning of April two peaks in SDI-Crocus are also seen by SDI-Phenocam. A peak then is not clearly seen by the digital camera. This could be due to the occurrence of two small snowfalls during the resurfacing of dust layers. At the end of April, the concentration of dust on the surface of snow is represented well, both by Crocus and digital images. During this last period, a marked change in snowmelt rate is observed from the snow depth 


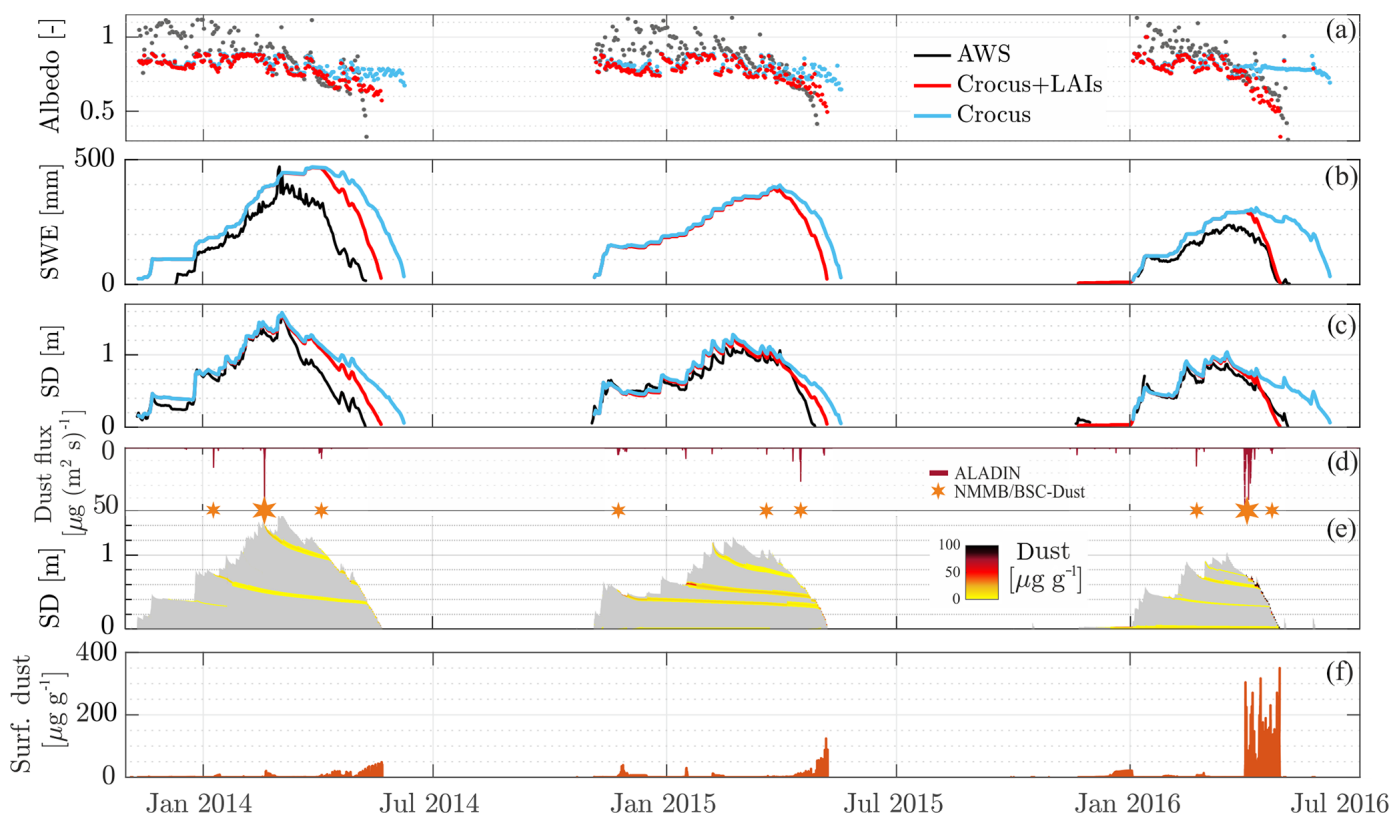

Figure 3. (a, b, c) Time series of albedo, snow water equivalent (SWE), and snow depth (SD) measured with the AWS and simulated with Crocus model including and excluding the impact of LAPs. SWE data are missing in December 2013 because of problems with the power supply. (d) Dust fluxes simulated with ALADIN (maroon bars, note that the scale is inverted), and strong (large stars) and weak (small stars) dust events simulated with NMMB/BSC-Dust. (e) Dust concentration $\left(\mu \mathrm{gg}^{-1}\right)$ in the snowpack (yellow to black palette) simulated with Crocus and superimposed on the snow depth profile (grey shaded area). (f) Surface concentration (averaged over the first $10 \mathrm{~cm}$ ) of dust simulated with Crocus.
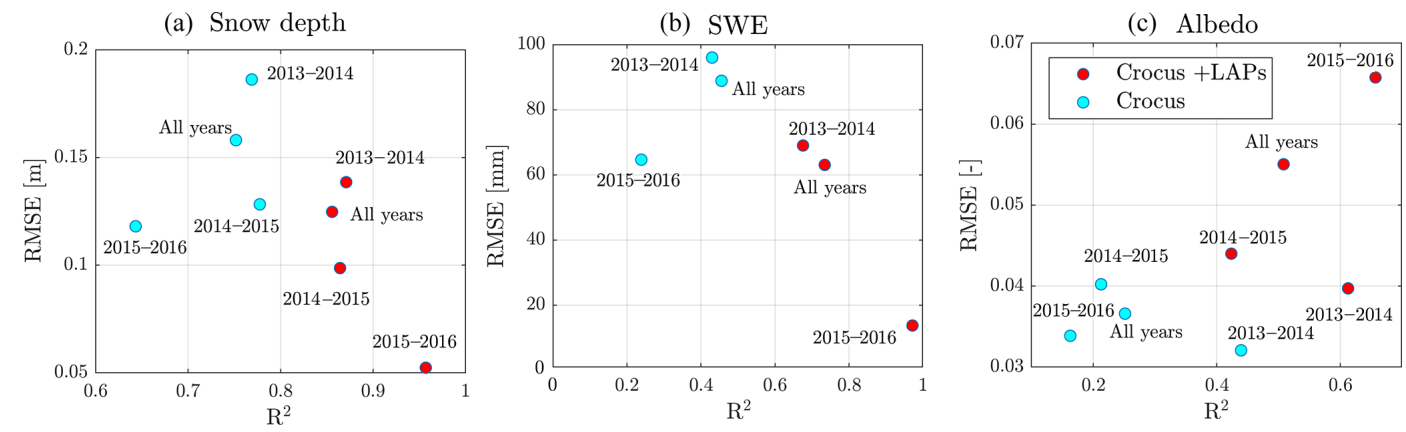

Figure 4. Comparison between (a) snow depth, (b) snow water equivalent (SWE), and (c) albedo observed from the AWS in Torgnon and simulated with Crocus accounting (red dots) and not accounting (cyan dots) for the impact of LAPs on snow.

series around the 20 April (Fig. 6). The agreement between SDI-Crocus and SDI-Phenocam suggests that low-cost digital RGB data can be used for monitoring the resurfacing of dust in snowfields, useful for satellite and model validation. In order to use these RGB data quantitatively, further comparisons with field spectroscopy and ground data are needed.

In Fig. $7 \mathrm{a}$ and $\mathrm{b}$, we show two examples of digital images collected from the digital camera. The spatial variability of SDI can be explained by local topography. The experimental site is located in a plain area, with a gentle slope $\left(\sim 5^{\circ}\right)$. Microtopography created by snow melting and refreezing cycles can locally concentrate and dilute impurities in the snowfield, also in relation to the differential sun ex- posure. Surface runoff may also represent an important process in shaping snow surface and in distributing dust in snowfields. This may explain the variability observed in SDI and also the differences between the measured dust concentration in snow samples and Crocus modelled concentrations. Dust redistribution on snowfields might strongly affect its radiative impact. In Fig. 7c and d, we present two SDI maps acquired before (10 April) and after (20 April) the resurfacing of dust layers. The transition from cold to warm colours reflects the increase in the values of the index. Positive values of the SDI are associated here with the presence of dust on snow (Di Mauro et al., 2015). On the right of both images, a snow pit is visible. It is interesting to note that in the SDI map 

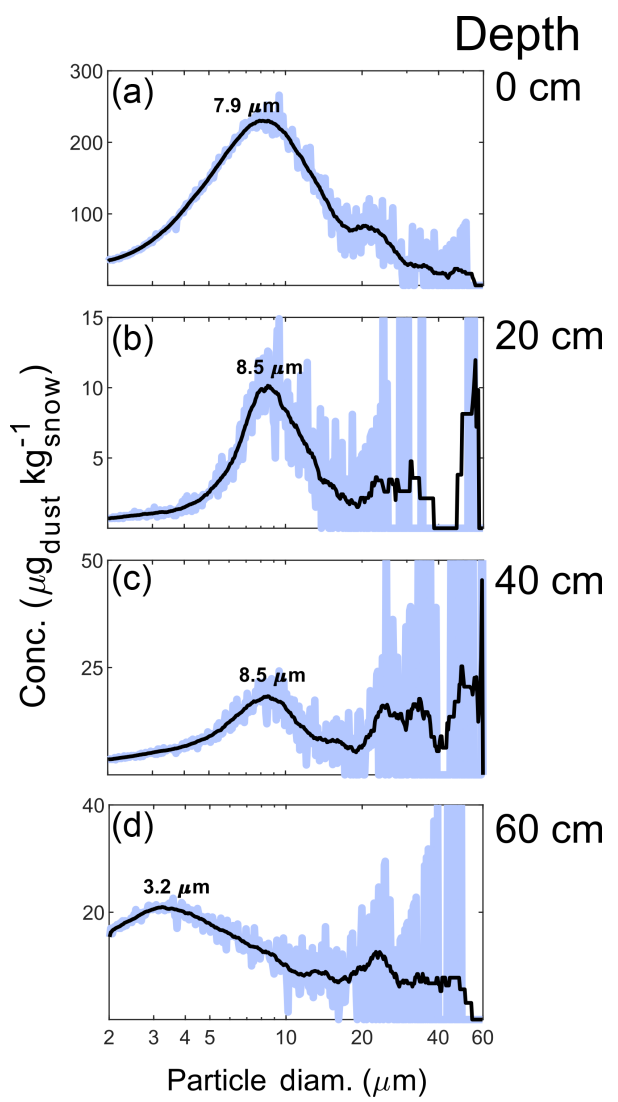

Figure 5. Dust particle distribution (expressed in $\mu g_{\text {dust }} \mathrm{kg}_{\text {snow }}^{-1}$ ) for a snow profile sampled at Torgnon on 6 April at different depths $(0,20,40$, and $60 \mathrm{~cm})$. Blue lines are experimental data, and black lines are moving averages (kernel: 25 points). Numbers in the plots represent the peak of the size distributions. Please note that the scale changes within different plots.

from 20 April, a red layer is visible in the snow pit. This can be possibly associated with the precedent weak depositions from February and March, which were concentrated in a thin snow layer by melting during early spring. At the end of the season, weak and strong depositions are concentrated by surface melting. This process amplifies the feedback mechanism of dust on snow. In fact, while the melting of snow concentrates the dust on the surface, higher concentrations of dust intensify the melting. This feedback is expected to act for each day with sufficient solar radiation during the melting period. The feedback is also expected to be enhanced until the total disappearing of the snow cover.

The SDI is also sensitive to other impurities, such as black carbon (Di Mauro et al., 2017) and organic material (Ganey et al., 2017). We cannot exclude that other impurities were present on snow surface, but at present we do not have enough data to evaluate these aspects. We interpret SDI variability only in relation to dust deposition and resurfacing. In the selected ROI (Fig. 7a), frequency distribution of the SDI shows a peak at 0.005 . Using this information,

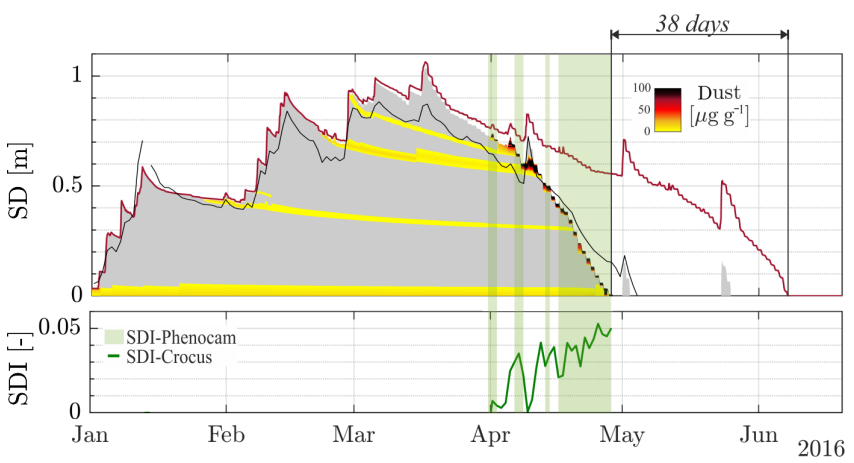

Figure 6. Comparison between snow depth simulated using Crocus with impurities (grey area) and without impurities (purple line). Observed data are also shown (black line). Dust concentration in snow is represented. Shaded green bands represent days with SDIPhenocam $>0$. SDI-Crocus is represented as a continuous green line.

we inverted the non-linear (rational) model developed in Di Mauro et al. (2015) that links mineral dust concentration and SDI values, and we obtained an estimated dust concentration equal to $56 \mu \mathrm{g}_{\text {dust }} \mathrm{g}_{\text {snow }}^{-1}$. This value is very close to the concentrations measured with the Coulter counter integrating particles smaller than $60 \mu \mathrm{m}$, which reached a maximum of $65 \mu \mathrm{g}_{\text {dust }} \mathrm{g}_{\text {snow }}^{-1}$.

Our estimations of shifts in the melt-out day are comparable to previous findings in the western US estimating a reduction of snow cover up to 51 days due to the presence of mineral dust in snow (Painter et al., 2007; Skiles et al., 2012). Despite the different deposition rates in the Alps, the advancement of the snowmelt due to dust is comparable to published results regarding the western US. This is true at least for one season (2015-2016) characterized by a major Saharan dust deposition. Tuzet et al. (2017) estimated up to $9 \mathrm{~d}$ of advanced snowmelt during 2014 in a lower elevation site located in the European Alps as well. In this paper, we estimate an advance in snow melt-out days of 18 , 11 , and $38 \mathrm{~d}$ for the three seasons considered. The estimation for the season 2015-2016 is very high, also considering that snow cover normally lasts about 7 months at this elevation $(2160 \mathrm{~m}$ a.s.1.). In the future, impurity concentration estimated with the atmospheric model should be evaluated using ground observations. In this sense, data from in situ spectrometers (e.g. Dumont et al., 2017; Picard et al., 2016) and repeated digital images can be very helpful. In fact, the concentration of different impurities may be retrieved from spectral reflectance using both inversion of radiative transfer models and spectral indices.

Dust transport is a natural phenomenon, but it can be intensified by anthropogenic activities (Neff et al., 2008). Further research is needed to assess possible inputs of local dust to mountain environments. Recently, dust was found to be more important than temperature in determining snowmelt in the western US (Painter et al., 2018). 


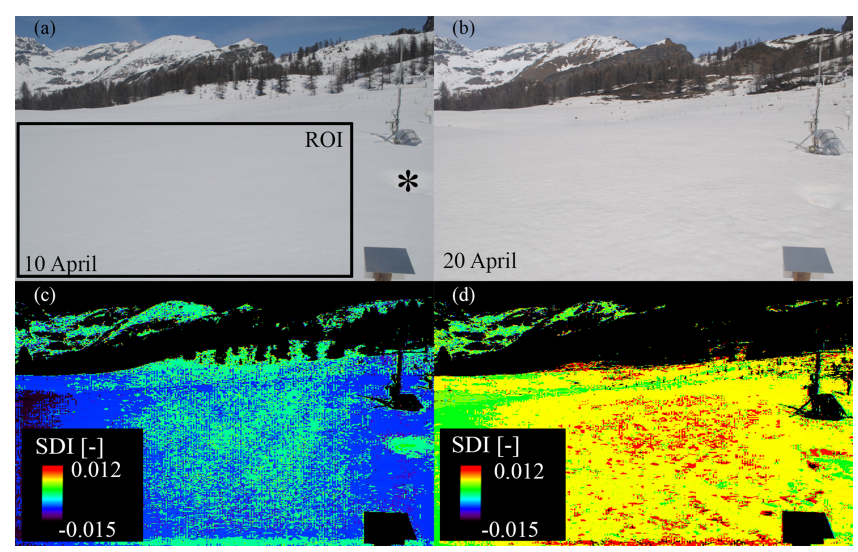

Figure 7. (a, b) Examples of digital images acquired from the Phenocam installed at Torgnon before and after the resurfacing of dust layers. (c, d) Snow darkening index (SDI) calculated using the red and green channels of the images. A region of interest (ROI, a) was used to create SDI time series. The asterisk in (a) indicates the position of the snow pit.

Although no trends were found in the annual number of Saharan dust days since 1997 (Flentje et al., 2015), further research is needed to assess the role of impurities on snow dynamics in the Alps. Measurements of surface concentrations of dust and black carbon in snow are very scarce in the whole Alpine chain. At the Jungfraujoch station (3454 m a.s.1.), dust concentration in the atmosphere is measured continuously (Collaud Coen et al., 2004). A comparison with these data will be fundamental in validating Saharan dust fluxes in the Alps and quantifying their effect on snow dynamics.

Snow duration was very short during the 2015-2016 hydrologic year. Usually, grassland in Torgnon is covered by a thick snow cover from the end of October to late May (average 1928-2010). During 2015-2016 snow arrived in January and disappeared at the beginning of May. It is known that earlier snowmelt impacts the carbon uptake period (Galvagno et al., 2013), altering carbon exchange with the atmosphere during spring. Shifts in phenological dates, such as the beginning and end of season, may impact ecosystem functioning related to net and gross ecosystem productivity in alpine grasslands and might lead to early depletion of soil moisture and early senescence related to summer water stress. Extreme events like heatwaves have impacts on phenology of mountain grasslands (Cremonese et al., 2017). With future climate change, these extreme events are likely to increase. With the intensification of climate change, snow is expected to occur later in autumn and to be depleted earlier in spring (Frei et al., 2018; Verfaillie et al., 2018), with significant consequences for the hydrological cycle. The effect of Saharan dust in the European Alps is to accelerate the melt via the direct and indirect effect on snow albedo, thus enhancing snow season shortening.

\subsection{Geochemical characterization of dust in snow}

Dust composition is strictly tied to its optical characteristics and hence to its radiative effect on snow (Caponi et al., 2017; Reynolds et al., 2013). Iron oxides contained in dust are particularly absorptive in the visible wavelengths (Alfaro et al., 2004; Linke et al., 2006), and this further enhances the albedo feedback when dust is deposited on snow. The composition of dust is also important for the correct representation of dust in radiative transfer models and global climate models (Albani et al., 2014). Saharan dust events provide an input of nutrients to alpine ecosystems (Goudie and Middleton, 2001), and this has been poorly studied in the scientific literature (Arvin et al., 2017).

The main source area of Saharan dust events reaching the Alps is represented by northern Algeria (potential source area in Northern Africa 1 - PSANAF-1 - in Formenti et al., 2011). For this reason, the dataset presented in this study can be considered representative for the main composition of long-range dust deposition on snow in the Alps. Saharan dust events are regional episodes that move large quantities of mineral dust from arid regions to different latitudes and longitudes. There are two main pathways for the transport of dust: it can reach Europe overpassing the Mediterranean and also by looping back over the Atlantic (Israelevich et al., 2012; Sodemann et al., 2006). For this reason, we can assume that the bulk geochemical composition of dust events that occurred in different locations in the Alps and at different times is comparable.

Between 18 and 20 February 2014 a relevant event was observed, involving not only southern Europe and the Alps but also a large fraction of Europe. It was described as one of the most intense events of this kind that was observed in previous years. The event was associated to a particularly favourable atmospheric setting which could uplift a massive amount of Saharan dust from northern Africa and transport it toward Europe in association to south-westerly winds driven by an anticyclonic structure located on the central Mediterranean. Given the magnitude of the event, many studies reported it, spanning from microbiology (Meola et al., 2015; Weil et al., 2017) to remote and proximal sensing (Dumont et al., 2017; Di Mauro et al., 2015; Tuzet et al., 2017) and atmospheric chemistry and physics (Belosi et al., 2017; Telloli et al., 2018).

Hereafter, we provide results from a geochemical characterization of dust sampled in snow in the Alps (Artavaggio, Lecco, Italy). The analysis of the elemental composition allowed detecting 36 elements, spanning from the so-called major elements (the ones whose oxides constitute more than $1 \%$ of the average composition of Earth's crust) to many minor and trace ones. Data of interest are shown in Fig. 8, the full list of elemental concentrations is reported in Table 1. We acknowledge that only one snow sample containing dust is not enough to provide a complete overview on the composition of Saharan dust in snow in the Alps, but our analysis 
may pave the way for a more exhaustive characterization of dust composition in the future.

The concentrations of major elements normalized to the upper continental crust composition are shown in Fig. 8a. It can be easily appreciated that SH1 and SH2 display a very different composition. SH1, corresponding to the dusty snow deposited during the Saharan advection episode of February 2014, presents a typical crustal signature, with UCC normalized values close to 1 . On the contrary, $\mathrm{SH} 2$ shows very low normalized concentrations, suggesting that in this case, the crustal fraction is not the dominant one. Since all the considered major elements are strongly depleted (normalized concentrations span from 0.17 in the case of $\mathrm{Na}$ to 0.38 for $\mathrm{Fe}$ ), it can be inferred that its composition is probably dominated by the only major element which is not considered here: carbon. Unfortunately INAA is not suited for its detection, but it is known that the carbonaceous fraction is an important component of snow impurities (Li et al., 2016; Wang et al., 2015). Comparing SH1 to Sahel and Saharan dust source composition, a substantial correspondence can be appreciated, as illustrated in Fig. 8. This is not unexpected, but direct observations linking the geochemical properties of Saharan dust to the dust deposited in the Alps are quite scarce.

One of the main differences between $\mathrm{SH} 1$ and $\mathrm{SH} 2$ is regarding iron $(\mathrm{Fe})$. With respect to this element, $\mathrm{SH} 1$ presents absolute concentrations that are more than 2 orders of magnitude higher than in SH2. This suggests that Saharan dust could be important for supplying this essential element to high-elevation alpine ecosystems where other nutrient sources could be limited, as already pointed out to in relation to other species and to other environments (Avila et al., 1998; Greilinger et al., 2018; Rizzolo et al., 2017). Another issue related to Fe concentration in atmospheric dust is related to its optical properties, since iron oxide concentration and mineralogy strongly influence them (Alfaro et al., 2004; Caponi et al., 2017; Formenti et al., 2014; Linke et al., 2006). The large abundance of $\mathrm{Fe}$ is thus expected to affect the radiative effects of dust on snow (Reynolds et al., 2013).

Looking at $\mathrm{Ca}$ and $\mathrm{Ti}$, further information can be inferred about the most likely provenance of SH1. Northern African sources (grey lines in Fig. 8a) can be clearly distinguished in relation to the content of these two elements, and indeed two groups are recognized. A first one is characterized by high $\mathrm{Ca}$ concentration and low Ti content, and the second group shows an opposite composition, with a larger amount of $\mathrm{Ti}$ and a lower amount of $\mathrm{Ca}$ (see Fig. 8a). Carbonates are rich in $\mathrm{Ca}$ (a constituent of these rocks) and poor in $\mathrm{Ti}$, in relation to their limited content in accessory and heavy minerals. The first group (high $\mathrm{Ca}$ and low $\mathrm{Ti}$ ) corresponds to the samples collected in Western Sahara, where carbonate rocks are common. On the contrary, samples from northern Africa display an opposed composition. Comparing SH1 to these groups, it is clear that its composition is in accordance with the second group. Its provenance is more probably related to the

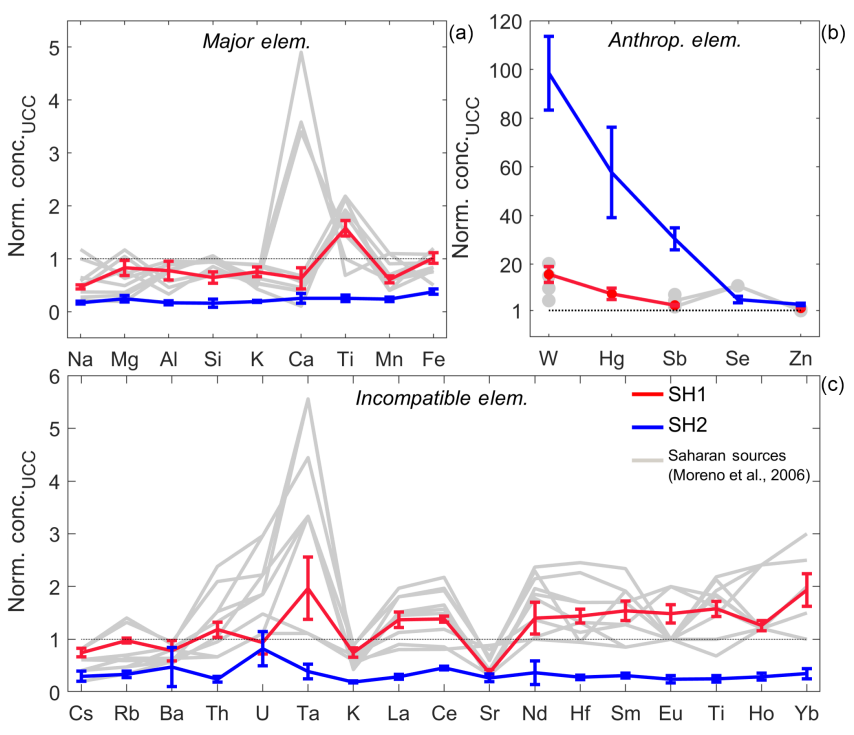

Figure 8. The elemental composition of the Saharan dust extracted from the snow precipitated on the Alps in February 2014 (red line, $\mathrm{SH} 1$ ), and the composition of the particulate matter retrieved from the clean snow deposited few days later (blue line, SH2). Grey lines refer to samples collected from the Sahara-Sahel dust corridor (Moreno et al., 2006). Data are expressed in terms of concentration normalized to the average upper continental crust (UCC; Rudnick and Gao, 2003). (a) Major elements, (b) anthropogenic elements, and (c) incompatible elements (with respect to $\mathrm{Fe}$ ), listed following the order proposed by Sun and McDonough (1989).

mobilization of dust from the central sector of the SaharaSahel dust corridor, i.e. the Hoggar, Chad, and Niger basins (Moreno et al., 2006).

The elemental composition of dust might also have an important effect on the biogeochemical cycles of the alpine grasslands. Among the elements listed in Table 1 there are elements such as $\mathrm{K}$ and $\mathrm{Ca}$ that are known to be relevant to ecosystem functioning (Sardans and Peñuelas, 2015; Schaffner et al., 2012). For both elements, SH1 shows notably higher concentrations (see Table 1). This requires more attention and further studies to understand the feedback of Saharan dust deposition on the biogeochemistry of highelevation ecosystems.

Anthropogenic elements are presented in Fig. 8b. They are $\mathrm{W}, \mathrm{Hg}, \mathrm{Sb}, \mathrm{Se}$, and $\mathrm{Zn}$. This group of elements concerns those elements presenting important positive deviations with respect to UCC composition. They are defined "anthropogenic" to highlight that the their biogeochemical cycles have been strongly impacted by human activities in the last decades and that their mobilization in the environment related to anthropogenic activities exceeds the natural one (Sen and Peucker-Ehrenbrink, 2012). Again, the signature of SH1 is completely different from that of SH2. Unlike the case of major and incompatible elements, for anthropogenic elements the sample presenting the higher relative concentra- 
Table 1. The elemental composition of SH1 (snow sample containing mineral dust) and SH2 (clean snow sample). Data are expressed (in terms of $\mu \mathrm{g} \mathrm{g}^{-1}$ ) and are referred to the mass of the extracted material, not to the considered snow volume. Values in brackets are measurement uncertainties. Normalized concentrations were calculated considering the upper continental crust as a reference (Rudnick and Gao, 2003).

\begin{tabular}{|c|c|c|c|c|}
\hline \multirow[t]{2}{*}{ Element } & \multicolumn{2}{|c|}{ SH1 } & \multicolumn{2}{|c|}{ SH2 } \\
\hline & $\begin{array}{r}\text { Conc. } \\
\left(\mu \mathrm{g} \mathrm{g}^{-1}\right)\end{array}$ & $\begin{array}{r}\text { Conc. } \\
\text { (UCC norm.) }\end{array}$ & $\begin{array}{r}\text { Conc. } \\
\left(\mu \mathrm{g} \mathrm{g}^{-1}\right)\end{array}$ & $\begin{array}{r}\text { Conc. } \\
\text { (UCC norm.) }\end{array}$ \\
\hline $\mathrm{Na}$ & $5600(500)$ & $0.47(0.04)$ & $2000(300)$ & $0.17(0.03)$ \\
\hline $\mathrm{Mg}$ & $12000(2000)$ & $0.8(0.1)$ & $3600(900)$ & $0.24(0.06)$ \\
\hline $\mathrm{Al}$ & $63000(14000)$ & $0.8(0.2)$ & $13500(3000)$ & $0.17(0.04)$ \\
\hline $\mathrm{Si}$ & $200000(35000)$ & $0.6(0.1)$ & $48000(25000)$ & $0.15(0.08)$ \\
\hline $\mathrm{K}$ & $17000(2000)$ & $0.75(0.09)$ & $4500(400)$ & $0.19(0.02)$ \\
\hline $\mathrm{Ca}$ & $16000(5000)$ & $0.6(0.2)$ & $6000(2000)$ & $0.25(0.09)$ \\
\hline $\mathrm{Ti}$ & 6000(500) & $1.6(0.1)$ & 900(200) & $0.25(0.06)$ \\
\hline $\mathrm{Mn}$ & $470(50)$ & $0.61(0.07)$ & $180(33)$ & $0.23(0.04)$ \\
\hline $\mathrm{Fe}$ & $40000(4000)$ & $1.0(0.1)$ & $180(30)$ & $0.38(0.05)$ \\
\hline $\mathrm{Sc}$ & $13(1)$ & $0.91(0.08)$ & $3.1(0.4)$ & $0.22(0.03)$ \\
\hline V & $100(10)$ & $1.0(0.1)$ & $26(5)$ & $0.27(0.05)$ \\
\hline $\mathrm{Cr}$ & $123(27)$ & $1.3(0.03)$ & $84(22)$ & $0.9(0.2)$ \\
\hline Co & 14(1) & $0.82(0.06)$ & $6.6(0.7)$ & $0.38(0.05)$ \\
\hline $\mathrm{Ni}$ & $35(8)$ & $0.7(0.2)$ & $38(11)$ & $0.8(0.2)$ \\
\hline $\mathrm{Zn}$ & 132(13) & $2.0(0.2)$ & $233(30)$ & $3.5(0.4)$ \\
\hline As & 6(1) & $1.3(0.2)$ & 4(1) & $0.9(0.2)$ \\
\hline $\mathrm{Se}$ & $<0.002$ & - & $0.5(0.1)$ & $5(1)$ \\
\hline $\mathrm{Rb}$ & $82(8)$ & $0.98(0.09)$ & $28(5)$ & $0.34(0.06)$ \\
\hline $\mathrm{Sr}$ & $118(19)$ & $0.37(0.06)$ & $86(23)$ & $0.27(0.07)$ \\
\hline $\mathrm{Sb}$ & $1.3(0.2)$ & $3.1(0.4)$ & $12(2)$ & $30(5)$ \\
\hline Cs & $3.7(0.4)$ & $0.75(0.08)$ & $1.5(0.2)$ & $0.30(0.05)$ \\
\hline $\mathrm{Ba}$ & $500(100)$ & $0.8(0.2)$ & $300(200)$ & $0.5(0.4)$ \\
\hline $\mathrm{La}$ & $43(5)$ & $1.4(0.1)$ & $9(2)$ & $0.29(0.05)$ \\
\hline $\mathrm{Ce}$ & $87(4)$ & $1.39(0.06)$ & $29(2)$ & $0.46(0.04)$ \\
\hline $\mathrm{Nd}$ & $38(8)$ & $1.4(0.3)$ & $10(6)$ & $0.4(0.2)$ \\
\hline $\mathrm{Sm}$ & $7.2(0.9)$ & $1.5(0.2)$ & $1.5(0.2)$ & $0.32(0.05)$ \\
\hline $\mathrm{Eu}$ & $1.5(0.2)$ & $1.5(0.2)$ & $0.24(0.07)$ & $0.24(0.07)$ \\
\hline $\mathrm{Tb}$ & $1.05(0.08)$ & $1.5(0.1)$ & $0.22(0.05)$ & $0.31(0.06)$ \\
\hline Но & $1.05(0.08)$ & $1.3(0.1)$ & $0.24(0.05)$ & $0.29(0.07)$ \\
\hline $\mathrm{Yb}$ & $3.9(0.6)$ & $1.9(0.3)$ & $0.7(0.2)$ & $0.3(0.1)$ \\
\hline $\mathrm{Hf}$ & $7.6(0.7)$ & $1.4(0.1)$ & $1.5(0.2)$ & $0.28(0.04)$ \\
\hline $\mathrm{Ta}$ & $1.8(0.5)$ & $2.0(0.6)$ & $0.4(0.1)$ & $0.4(0.1)$ \\
\hline $\mathrm{W}$ & $3.1(0.7)$ & $16(3)$ & 19(3) & $100(15)$ \\
\hline $\mathrm{Hg}$ & $0.4(0.1)$ & $8(2)$ & $2.9(0.9)$ & $60(20)$ \\
\hline Th & 12(1) & $1.2(0.1)$ & $2.6(0.6)$ & $0.24(0.05)$ \\
\hline $\mathrm{U}$ & $2.5(0.6)$ & $0.9(0.2)$ & $2.2(0.9)$ & $0.8(0.3)$ \\
\hline
\end{tabular}

tion is $\mathrm{SH}$ 2. SH1 shows values near 1, suggesting that its composition is also mainly crustal for these elements. On the contrary, sample SH2 presents extremely high enrichments, near 100 in the case of W. Such values are not compatible with a crustal origin. Contributions from other sources must be involved. Atmospheric emissions related to human activities are the best candidate for explaining the enrichment of almost all of these elements. $\mathrm{Hg}, \mathrm{Sb}, \mathrm{Se}$, and $\mathrm{Zn}$ are all quite volatile elements, are easily mobilized in the atmosphere, and are related to industrial processes. Indeed, the sampling site is located less than $100 \mathrm{~km}$ far from the Po Valley, one of the most industrialized and densely inhabited regions of Eu- rope. The same interpretation is not sufficient for explaining the considerably high amount of $\mathrm{W}$ in $\mathrm{SH} 2$. There is no previous available information about its occurrence in snow, and in general its behaviour in the environment is quite obscure (Koutsospyros et al., 2006). It is traditionally considered a non-volatile element, given its refractory properties. The high concentration found in $\mathrm{SH} 2$ could be related to the anthropogenic activities, since $\mathrm{W}$ is used in many industrial and manufacturing activities (Koutsospyros et al., 2006). Thus, a different transport mechanism is probably involved. Volatile elements can easily be scavenged from the atmosphere after being adsorbed on particulate matter (Marx et 
al., 2008), refractory and non-volatile elements are instead more easily transported directly as airborne particles generated by industrial processes (Sheppard et al., 2007).

The composition of a suite of elements found in trace is presented in Fig. 8c. The elements displayed there were ordered following their incompatibility degree with respect to $\mathrm{Fe}$ (Sun and McDonough, 1989). This is a useful geochemical feature for understanding the provenance and the geochemical signature of rock-related samples. Focussing on $\mathrm{SH} 1$, it can be appreciated that there is a slight enrichment of poorly incompatible elements (the ones on the right side of Fig. 8c). The same feature is also recognized in the African dust sources, as it was extensively discussed by Moreno et al. (2006), which related the point to the geochemical and mineralogical properties of the sources. Sr and Ta are the two elements presenting the most evident anomalies: a depletion in the first case and an enrichment in the second case. The concentration of $\mathrm{Sr}$ is generally related to the presence or absence of carbonates, since $\mathrm{Sr}$ is a well-known substituent for $\mathrm{Ca}$ in carbonate lattice. In Fig. 8c, it is possible to appreciate that $\mathrm{SH} 1$ and most of the African sources are significantly depleted in $\mathrm{Sr}$, confirming what was already suggested by major elements. Indeed, the samples with low Sr content are the same samples presenting low $\mathrm{Ca}$ concentrations, pointing to a limited presence of carbonates and confirming that sources from Western Sahara were not involved in this episode.

The case of Ta is completely different, given the analytical difficulties related to its detection; its behaviour in the environment is not yet well constrained, but it seems quite common to deal with samples that present an enrichment, in particular when atmosphere-related samples are considered (Filella, 2017). Looking at Fig. 8c, it can be seen that both the African sources, and to a lesser extent SH1, present a positive anomaly for Ta. Recent studies suggested that the Ta enrichment in rocks, sediments, and atmospheric particulate matter could be attributed to the effect of chemical weathering. Being extremely stable from a chemical and geochemical perspective, the loss of mobile fractions during weathering, enhanced by atmospheric transport, could explain the enrichment of Ta (Baccolo et al., 2016; Vlastelic et al., 2015).

\section{Conclusions}

In this paper, we investigated the role of impurity depositions in snow dynamics. In particular, we analysed the role of Saharan dust events on snowmelt in a high-elevation site of the European Alps. We estimated that impurities induced an advance in snow melt-out dates of $38 \mathrm{~d}$ for the season 20152016. During the other seasons considered here (2013-2014 and 2014-2015), the advancement in snow melt-out dates was 18 and $11 \mathrm{~d}$, respectively. The season 2015-2016 was characterized by dust depositions that were almost double with respect to the other years considered in this study. Snow key variables (snow water equivalent, snow albedo, and snow depth) simulated with Crocus model were compared with observed variables from an AWS in the Aosta Valley (western Alps). Good agreement between observations and simulations accounting for the role of impurities was observed. The size distribution of dust found in snow confirms the Saharan origin of the event during April 2016 (Baumann-Stanzer et al., 2018). The geochemical characterization of dust and particulate matter samples distinguished the snow associated with Saharan dust from clean snow. Dusty snow showed a composition compatible with the geochemistry of the dust sources located in the central sector of the Sahara-Sahel dust corridor, i.e. the Hoggar, Chad, and Niger basin northern African sources. On the contrary, clean snow was characterized by strong contaminations related to anthropogenic elements. These results demonstrate that an accurate geochemical characterization of dust deposited on the Alps allows the identification of the different Saharan sources involved in the single transport events, but the fingerprint of the local sources may also play an important role.

In the paper, we also made use of repeated digital images for monitoring dust deposition and resurfacing in the snowpack of Torgnon. Dust deposition and resurfacing agreed well with modelling predictions. This allowed us to propose the use of an RGB index (i.e. snow darkening index - SDI) for tracking dust on snow using repeated digital images from digital cameras. The good agreement between dust deposition and the SDI suggests that data from this experimental site can be used as a possible calibration and validation for satellite imagery (e.g. MODIS, Landsat, and Sentinel) and for regional and global climate model (WFR-Chem and CLM) validation.

Several questions are still open regarding the role of dust in the Alps. For example, the spatial distribution of dust concentration on snow at alpine scale has never been quantitatively estimated. Possible differences between eastern and western Alps may arise as a function of distance from the sources. Another unresolved issue is the input from local sources: coarser dust particles can be suspended from snow-free areas and deposited on snow. Regarding the geochemical and mineralogical characteristics of dust, future research should explore, in detail, the relation between dust characteristics and their radiative effect on snow. In addition to the wellknown snow-albedo feedback, other complex mechanisms can influence the impact of dust on snow. For example, the presence of dissolved carbonates may accelerate the melt of snow lowering the melting point of snow and ice crystals. The role of carbonaceous particles on snow optical properties in the Alps is also an open question. Measurements of black carbon, brown carbon, organic carbon, and elemental carbon concentration in snow are virtually absent in surface snow in the Alps. The Po Plain is one of the most polluted areas of the planet. At lower elevations, black carbon emissions from fossil fuel combustion and biomass burning may reach snowcovered areas and exert an impact on snow optical properties. Future research efforts should aim at providing spatially 
distributed measurements of carbonaceous particles, and this will be a fundamental contribution in the determination of the role of natural and anthropogenic activity on snowmelt at the regional scale.

Data availability. Data used in this paper will be made available upon request to the first author.

Author contributions. BDM conceived the idea of the research, analysed the data, and wrote the paper with contributions from all other authors. RG analysed data from the AWS and Crocus. MG, GF, PP, UMdC, and EC established and maintained the experimental site in Torgnon, provided the data from AWS, and analysed RGB data from the Phenocam. MD, FT, and ML created Crocus simulations and helped in their interpretation. GB, MC, BD, and VM measured dust concentration and geochemical composition and helped in their interpretation. MM helped in the interpretation of the geochemical data. MR, SM, EC, and RC supervised the research.

Competing interests. The authors declare that they have no conflict of interest.

Acknowledgements. We acknowledge the ARPA (Environmental Protection Agency) of the Aosta Valley region for maintaining the AWS in Torgnon and for providing the dataset. RGB images were analysed using the Phenopix R package (https://r-forge. r-project.org/projects/phenopix/, last access: 2 April 2019). The complete set of Phenocam images is available at the following website: https://phenocam.sr.unh.edu/webcam/sites/torgnon-nd/ (last access: 2 April 2019). Edoardo Cremonese acknowledges the support of the NextData Data-LTER-Mountain project CNRM. CEN and IGE are part of Labex OSUG@ 2020. The modelling work was funded by the ANRJCJC EBONI grant no. 16-CE01-0006. We thank the editor and the two reviewers for the constructive comments on a previous version of the paper.

Review statement. This paper was edited by Jürg Schweizer and reviewed by Stanislav Kutuzov and Marion Greilinger.

\section{References}

Aciego, S. M., Riebe, C. S., Hart, S. C., Blakowski, M. A., Carey, C. J., Aarons, S. M., Dove, N. C., Botthoff, J. K., Sims, K. W. W., and Aronson, E. L.: Dust outpaces bedrock in nutrient supply to montane forest ecosystems, Nat. Commun., 8, 14800, https://doi.org/10.1038/ncomms14800, 2017.

Albani, S., Mahowald, N. M., Perry, A. T., Scanza, R. A., Zender, C. S., Heavens, N. G., Maggi, V., Kok, J. F., and OttoBliesner, B. L.: Improved dust representation in the Community Atmosphere Model, J. Adv. Model. Earth Syst., 6, 541-570, https://doi.org/10.1002/2013MS000279, 2014.
Alfaro, S. C., Lafon, S., Rajot, J. L., Formenti, P., Gaudichet, A., and Maillé, M.: Iron oxides and light absorption by pure desert dust: An experimental study, J. Geophys. Res., 109, D08208, https://doi.org/10.1029/2003JD004374, 2004.

Arvin, L. J., Riebe, C. S., Aciego, S. M., and Blakowski, M. A.: Global patterns of dust and bedrock nutrient supply to montane ecosystems, Sci. Adv., 3, eaao1588, https://doi.org/10.1126/sciadv.aao1588, 2017.

Avila, A. and Peñuelas, J.: Increasing frequency of Saharan rains over northeastern Spain and its ecological consequences, Sci. Total Environ., 228, 153-156, https://doi.org/10.1016/S00489697(99)00041-8, 1999.

Avila, A., Alarcón, M., and Queralt, I.: The chemical composition of dust transported in red rains - its contribution to the biogeochemical cycle of a holm oak forest in Catalonia (Spain), Atmos. Environ., 32, 179-191, https://doi.org/10.1016/S13522310(97)00286-0, 1998.

Baccolo, G., Maffezzoli, N., Clemenza, M., Delmonte, B., Prata, M., Salvini, A., Maggi, V., and Previtali, E.: Low-background neutron activation analysis: a powerful tool for atmospheric mineral dust analysis in ice cores, J. Radioanal. Nucl. Chem., 306 , 589-597, https://doi.org/10.1007/s10967-015-4206-2, 2015.

Baccolo, G., Clemenza, M., Delmonte, B., Maffezzoli, N., Nastasi, M., Previtali, E., Prata, M., Salvini, A., and Maggi, V.: A new method based on low background instrumental neutron activation analysis for major, trace and ultra-trace element determination in atmospheric mineral dust from polar ice cores, Anal. Chim. Acta, 922, 11-18, https://doi.org/10.1016/J.ACA.2016.04.008, 2016.

Baumann-Stanzer, K., Greilinger, M., Kasper-Giebl, A., Flandorfer, C., Hieden, A., Lotteraner, C., Ortner, M., Vergeiner, J., Schauer, G., and Piringer, M.: Evaluation of WRF-Chem Model Forecasts of a Prolonged Sahara Dust Episode over the Eastern Alps, Aerosol Air Qual. Res., https://doi.org/10.4209/aaqr.2018.03.0116, in press, 2018.

Belosi, F., Rinaldi, M., Decesari, S., Tarozzi, L., Nicosia, A., and Santachiara, G.: Ground level ice nuclei particle measurements including Saharan dust events at a Po Valley rural site (San Pietro Capofiume, Italy), Atmos. Res., 186, 116-126, https://doi.org/10.1016/J.ATMOSRES.2016.11.012, 2017.

Beniston, M.: Mountain Climates and Climatic Change: An Overview of Processes Focusing on the European Alps, Pure Appl. Geophys., 162, 1587-1606, https://doi.org/10.1007/s00024-005-2684-9, 2005.

Beniston, M., Keller, F., and Goyette, S.: Snow pack in the Swiss Alps under changing climatic conditions: An empirical approach for climate impacts studies, Theor. Appl. Climatol., 74, 19-31, https://doi.org/10.1007/s00704-002-0709-1, 2003.

Beniston, M., Farinotti, D., Stoffel, M., Andreassen, L. M., Coppola, E., Eckert, N., Fantini, A., Giacona, F., Hauck, C., Huss, M., Huwald, H., Lehning, M., López-Moreno, J.-I., Magnusson, J., Marty, C., Morán-Tejéda, E., Morin, S., Naaim, M., Provenzale, A., Rabatel, A., Six, D., Stötter, J., Strasser, U., Terzago, S., and Vincent, C.: The European mountain cryosphere: a review of its current state, trends, and future challenges, The Cryosphere, 12, 759-794, https://doi.org/10.5194/tc-12-759-2018, 2018.

Borio di Tigliole, A., Cammi, A., Clemenza, M., Memoli, V., Pattavina, L., and Previtali, E.: Benchmark evaluation of reactor critical parameters and neutron fluxes distributions at zero power for the TRIGA Mark II reactor of the University of Pavia using 
the Monte Carlo code MCNP, Prog. Nucl. Energy, 52, 494-502, https://doi.org/10.1016/j.pnucene.2009.11.002, 2010.

Brown, R. D. and Robinson, D. A.: Northern Hemisphere spring snow cover variability and change over 1922-2010 including an assessment of uncertainty, The Cryosphere, 5, 219-229, https://doi.org/10.5194/tc-5-219-2011, 2011.

Brown, R. D., Mote, P. W., Brown, R. D., and Mote, P. W.: The Response of Northern Hemisphere Snow Cover to a Changing Climate, J. Climate, 22, 2124-2145, https://doi.org/10.1175/2008JCLI2665.1, 2009.

Brun, E., Martin, E., Simon, V., Gendre, C., and Coleou, C.: An Energy and Mass Model of Snow Cover Suitable for Operational Avalanche Forecasting, J. Glaciol., 35, 333-342, https://doi.org/10.3189/S0022143000009254, 1989.

Brun, E., David, P., Sudul, M., and Brunot, G.: A numerical model to simulate snow-cover stratigraphy for operational avalanche forecasting, J. Glaciol., 38, 13-22, https://doi.org/10.3189/S0022143000009552, 1992.

Callot, Y., Marticorena, B., and Bergametti, G.: Geomorphologic approach for modelling the surface features of arid environments in a model of dust emissions: Application to the sahara desert, Geodin. Acta, 13, 245-270, https://doi.org/10.1080/09853111.2000.11105373, 2000.

Caponi, L., Formenti, P., Massabó, D., Di Biagio, C., Cazaunau, M., Pangui, E., Chevaillier, S., Landrot, G., Andreae, M. O., Kandler, K., Piketh, S., Saeed, T., Seibert, D., Williams, E., Balkanski, Y., Prati, P., and Doussin, J.-F.: Spectral- and size-resolved mass absorption efficiency of mineral dust aerosols in the shortwave spectrum: a simulation chamber study, Atmos. Chem. Phys., 17, 7175-7191, https://doi.org/10.5194/acp-17-7175-2017, 2017.

Cohen, J. M., Lajeunesse, M. J., and Rohr, J. R.: A global synthesis of animal phenological responses to climate change, Nat. Clim. Change, 8, 224-228, https://doi.org/10.1038/s41558-018-00673, 2018 .

Collaud Coen, M., Weingartner, E., Schaub, D., Hueglin, C., Corrigan, C., Henning, S., Schwikowski, M., and Baltensperger, U.: Saharan dust events at the Jungfraujoch: detection by wavelength dependence of the single scattering albedo and first climatology analysis, Atmos. Chem. Phys., 4, 2465-2480, https://doi.org/10.5194/acp-4-2465-2004, 2004.

Corripio, J.: Snow surface albedo estimation using terrestrial photography, Int. J. Remote Sens., 25, 5705-5729, https://doi.org/10.1080/01431160410001709002, 2004.

Cremonese, E., Filippa, G., Galvagno, M., Siniscalco, C., Oddi, L., Morra di Cella, U., and Migliavacca, M.: Heat wave hinders green wave: The impact of climate extreme on the phenology of a mountain grassland, Agric. For. Meteorol., 247, 320-330, https://doi.org/10.1016/J.AGRFORMET.2017.08.016, 2017.

Dagsson-Waldhauserova, P., Arnalds, O., Olafsson, H., Hladil, J., Skala, R., Navratil, T., Chadimova, L., and Meinander, O.: Snow-Dust Storm: Unique case study from Iceland, March 6-7, 2013, Aeolian Res., 16, 69-74, https://doi.org/10.1016/j.aeolia.2014.11.001, 2015.

De Angelis, M. and Gaudichet, A.: Saharan dust deposition over Mont Blanc (French Alps) during the last 30 years, Tellus B, 43, 61-75, https://doi.org/10.3402/tellusb.v43i1.15246, 1991.

Di Mauro, B., Fava, F., Ferrero, L., Garzonio, R., Baccolo, G., Delmonte, B., and Colombo, R.: Mineral dust impact on snow radiative properties in the European Alps combining ground, UAV, and satellite observations, J. Geophys. Res.-Atmos., 120, 60806097, https://doi.org/10.1002/2015JD023287, 2015.

Di Mauro, B., Baccolo, G., Garzonio, R., Giardino, C., Massabò, D., Piazzalunga, A., Rossini, M., and Colombo, R.: Impact of impurities and cryoconite on the optical properties of the Morteratsch Glacier (Swiss Alps), The Cryosphere, 11, 2393-2409, https://doi.org/10.5194/tc-11-2393-2017, 2017.

Drake, J. J.: The Effects of Surface Dust on Snowmelt Rates, Arct. Alp. Res., 13, 219, https://doi.org/10.2307/1551197, 1981.

Dumont, M., Sirguey, P., Arnaud, Y., and Six, D.: Monitoring spatial and temporal variations of surface albedo on Saint Sorlin Glacier (French Alps) using terrestrial photography, The Cryosphere, 5, 759-771, https://doi.org/10.5194/tc-5-759-2011, 2011.

Dumont, M., Arnaud, L., Picard, G., Libois, Q., Lejeune, Y., Nabat, P., Voisin, D., and Morin, S.: In situ continuous visible and nearinfrared spectroscopy of an alpine snowpack, The Cryosphere, 11, 1091-1110, https://doi.org/10.5194/tc-11-1091-2017, 2017.

Field, J. P., Belnap, J., Breshears, D. D., Neff, J. C., Okin, G. S., Whicker, J. J., Painter, T. H., Ravi, S., Reheis, M. C., and Reynolds, R. L.: The ecology of dust, Front. Ecol. Environ., 8, 423-430, https://doi.org/10.1890/090050, 2010.

Filella, M.: Tantalum in the environment, Earth-Sci. Rev., 173, 122 140, https://doi.org/10.1016/J.EARSCIREV.2017.07.002, 2017.

Filippa, G., Cremonese, E., Migliavacca, M., Galvagno, M., Forkel, M., Wingate, L., Tomelleri, E., Morra di Cella, U., and Richardson, A. D.: Phenopix: A R package for image-based vegetation phenology, Agric. For. Meteorol., 220, 141-150, https://doi.org/10.1016/J.AGRFORMET.2016.01.006, 2016.

Flanner, M. G., Liu, X., Zhou, C., Penner, J. E., and Jiao, C.: Enhanced solar energy absorption by internally-mixed black carbon in snow grains, Atmos. Chem. Phys., 12, 4699-4721, https://doi.org/10.5194/acp-12-4699-2012, 2012.

Flentje, H., Briel, B., Beck, C., Collaud Coen, M., Fricke, M., Cyrys, J., Gu, J., Pitz, M., and Thomas, W.: Identification and monitoring of Saharan dust: An inventory representative for south Germany since 1997, Atmos. Environ., 109, 87-96, https://doi.org/10.1016/J.ATMOSENV.2015.02.023, 2015.

Formenti, P., Schütz, L., Balkanski, Y., Desboeufs, K., Ebert, M., Kandler, K., Petzold, A., Scheuvens, D., Weinbruch, S., and Zhang, D.: Recent progress in understanding physical and chemical properties of African and Asian mineral dust, Atmos. Chem. Phys., 11, 8231-8256, https://doi.org/10.5194/acp11-8231-2011, 2011.

Formenti, P., Caquineau, S., Chevaillier, S., Klaver, A., Desboeufs, K., Rajot, J. L., Belin, S., and Briois, V.: Dominance of goethite over hematite in iron oxides of mineral dust from Western Africa: Quantitative partitioning by X-ray absorption spectroscopy, J. Geophys. Res.-Atmos., 119, 12740-12754, https://doi.org/10.1002/2014JD021668, 2014.

Francis, D., Eayrs, C., Chaboureau, J.-P., Mote, T., and Holland, D. M.: Polar Jet Associated Circulation Triggered a Saharan Cyclone and Derived the Poleward Transport of the African Dust Generated by the Cyclone, J. Geophys. Res.-Atmos., 123, 11899-11917, https://doi.org/10.1029/2018JD029095, 2018.

Frei, P., Kotlarski, S., Liniger, M. A., and Schär, C.: Future snowfall in the Alps: projections based on the EUROCORDEX regional climate models, The Cryosphere, 12, 1-24, https://doi.org/10.5194/tc-12-1-2018, 2018. 
Gabbi, J., Huss, M., Bauder, A., Cao, F., and Schwikowski, M.: The impact of Saharan dust and black carbon on albedo and long-term mass balance of an Alpine glacier, The Cryosphere, 9, 13851400, https://doi.org/10.5194/tc-9-1385-2015, 2015.

Galvagno, M., Wohlfahrt, G., Cremonese, E., Rossini, M., Colombo, R., Filippa, G., Julitta, T., Manca, G., Siniscalco, C., Morra di Cella, U., and Migliavacca, M.: Phenology and carbon dioxide source/sink strength of a subalpine grassland in response to an exceptionally short snow season, Environ. Res. Lett., 8, 025008, https://doi.org/10.1088/1748-9326/8/2/025008, 2013.

Ganey, G. Q., Loso, M. G., Burgess, A. B., and Dial, R. $\mathrm{J} .:$ The role of microbes in snowmelt and radiative forcing on an Alaskan icefield, Nat. Geosci., 10, 754-759, https://doi.org/10.1038/ngeo3027, 2017.

Garzonio, R., Di Mauro, B., Cogliati, S., Rossini, M., Panigada, C., Delmonte, B., Maggi, V., and Colombo, R.: A novel hyperspectral system for high resolution imaging of ice cores: Application to light-absorbing impurities and ice structure, Cold Reg. Sci. Technol., 155, 47-57, https://doi.org/10.1016/J.COLDREGIONS.2018.07.005, 2018.

Gautam, R., Hsu, N. C., Lau, W. K.-M., and Yasunari, T. J.: Satellite observations of desert dust-induced Himalayan snow darkening, Geophys. Res. Lett., 40, 988-993, https://doi.org/10.1002/grl.50226, 2013.

Ginoux, P.: Warming or cooling dust?, Nat. Geosci., 10, 246-248, https://doi.org/10.1038/ngeo2923, 2017.

Goudie, A. S. and Middleton, N. J.: Saharan dust storms: nature and consequences, Earth-Sci. Rev., 56, 179-204, https://doi.org/10.1016/S0012-8252(01)00067-8, 2001.

Greenberg, R. R., Bode, P., and De Nadai Fernandes, E. A.: Neutron activation analysis: A primary method of measurement, Spectrochim, Spectrochim. Acta B, 66, 193-241, https://doi.org/10.1016/j.sab.2010.12.011, 2011.

Greilinger, M., Schauer, G., Baumann-Stanzer, K., Skomorowski, P., Schöner, W., and Kasper-Giebl, A.: Contribution of Saharan Dust to Ion Deposition Loads of High Alpine Snow Packs in Austria (1987-2017), Front. Earth Sci., 6, 126, https://doi.org/10.3389/feart.2018.00126, 2018.

Haeberli, W.: Sahara dust in the Alps, A short review, Z. Gletscherk. Glazialgeol., 13, 206-208, 1977.

Hansen, J. and Nazarenko, L.: Soot climate forcing via snow and ice albedos, P. Natl. Acad. Sci. USA, 101, 423-428, https://doi.org/10.1073/pnas.2237157100, 2004.

Hinkler, J., Pedersen, S. B., Rasch, M., and Hansen, B. U.: Automatic snow cover monitoring at high temporal and spatial resolution, using images taken by a standard digital camera, Int. J. Remote Sens., 23, 4669-4682, https://doi.org/10.1080/01431160110113881, 2002.

Huss, M., Bookhagen, B., Huggel, C., Jacobsen, D., Bradley, R. S., Clague, J. J., Vuille, M., Buytaert, W., Cayan, D. R., Greenwood, G., Mark, B. G., Milner, A. M., Weingartner, R., and Winder, M.: Toward mountains without permanent snow and ice Earth's Future, Earths Future, 5, 418-435, https://doi.org/10.1002/2016EF000514, 2017.

Israelevich, P., Ganor, E., Alpert, P., Kishcha, P., and Stupp, A.: Predominant transport paths of Saharan dust over the Mediterranean Sea to Europe, J. Geophys. Res.-Atmos., 117, D02205, https://doi.org/10.1029/2011JD016482, 2012.
Jickells, T. D.: Global Iron Connections Between Desert Dust, Ocean Biogeochemistry, and Climate, Science, 308, 67-71, https://doi.org/10.1126/science.1105959, 2005.

Jones, H. A.: Effect of dust on the melting of snow, Mon. Weather Rev., 41, 599-599, https://doi.org/10.1175/15200493(1913)41<599a:EODOTM>2.0.CO;2, 1913.

Julitta, T., Cremonese, E., Migliavacca, M., Colombo, R., Galvagno, M., Siniscalco, C., Rossini, M., Fava, F., Cogliati, S., Morra, U., and Menzel, A.: Agricultural and Forest Meteorology Using digital camera images to analyse snowmelt and phenology of a subalpine grassland, Agric. For. Meteorol., 198-199, 116125, https://doi.org/10.1016/j.agrformet.2014.08.007, 2014.

Jung, J., Box, J. E., Balog, J. D., Ahn, Y., Decker, D. T., and Hawbecker, P.: Greenland glacier calving rates from Extreme Ice Survey (EIS) time lapse photogrammetry, Am. Geophys. Union, available at: http://adsabs.harvard.edu/abs/2010AGUFM. C23B0628J (last access: 30 November 2015), 2010.

Kandler, K., Benker, N., Bundke, U., Cuevas, E., Ebert, M., Knippertz, P., Rodríguez, S., Schütz, L., and Weinbruch, S.: Chemical composition and complex refractive index of Saharan Mineral Dust at Izaña, Tenerife (Spain) derived by electron microscopy, Atmos. Environ., 41, 8058-8074, https://doi.org/10.1016/j.atmosenv.2007.06.047, 2007.

Kochendorfer, J., Nitu, R., Wolff, M., Mekis, E., Rasmussen, R., Baker, B., Earle, M. E., Reverdin, A., Wong, K., Smith, C. D., Yang, D., Roulet, Y.-A., Buisan, S., Laine, T., Lee, G., Aceituno, J. L. C., Alastrué, J., Isaksen, K., Meyers, T., Brækkan, R., Landolt, S., Jachcik, A., and Poikonen, A.: Analysis of singleAlter-shielded and unshielded measurements of mixed and solid precipitation from WMO-SPICE, Hydrol. Earth Syst. Sci., 21, 3525-3542, https://doi.org/10.5194/hess-21-3525-2017, 2017.

Kokhanovsky, A. A. and Zege, E. P.: Scattering optics of snow, Appl. Opt., 43, 1589, https://doi.org/10.1364/AO.43.001589, 2004.

Koutsospyros, A., Braida, W., Dermatas, D., and Strigul, N.: A review of tungsten: From environmental obscurity to scrutiny, J. Hazard. Mater., 136, 1-19, https://doi.org/10.1016/J.JHAZMAT.2005.11.007, 2006.

Krueger, B. J., Grassian, V. H., Cowin, J. P., and Laskin, A.: Heterogeneous chemistry of individual mineral dust particles from different dust source regions: The importance of particle mineralogy, Atmos. Environ., 38, 6253-6261, https://doi.org/10.1016/j.atmosenv.2004.07.010, 2004.

Kumar, A., Abouchami, W., Galer, S. J. G., Singh, S. P., Fomba, K. W., Prospero, J. M., and Andreae, M. O.: Seasonal radiogenic isotopic variability of the African dust outflow to the tropical Atlantic Ocean and across to the Caribbean, Earth Planet. Sc. Lett., 487, 94-105, https://doi.org/10.1016/J.EPSL.2018.01.025, 2018

Kutuzov, S., Shahgedanova, M., Mikhalenko, V., Ginot, P., Lavrentiev, I., and Kemp, S.: High-resolution provenance of desert dust deposited on Mt. Elbrus, Caucasus in 2009-2012 using snow pit and firn core records, The Cryosphere, 7, 1481-1498, https://doi.org/10.5194/tc-7-1481-2013, 2013.

Lawrence, C. R., Painter, T. H., Landry, C. C., and Neff, J. C.: Contemporary geochemical composition and flux of aeolian dust to the San Juan Mountains, Colorado, United States, J. Geophys. Res., 115, G03007, https://doi.org/10.1029/2009JG001077, 2010. 
Li, C., Chen, P., Kang, S., Yan, F., Li, X., Qu, B., and Sillanpää, M.: Carbonaceous matter deposition in the high glacial regions of the Tibetan Plateau, Atmos. Environ., 141, 203-208, https://doi.org/10.1016/J.ATMOSENV.2016.06.064, 2016.

Liao, H. and Seinfeld, J. H.: Radiative forcing by mineral dust aerosols: Sensitivity to key variables, J. Geophys. Res.-Atmos., 103, 31637-31645, https://doi.org/10.1029/1998JD200036, 1998.

Libois, Q., Picard, G., France, J. L., Arnaud, L., Dumont, M., Carmagnola, C. M., and King, M. D.: Influence of grain shape on light penetration in snow, The Cryosphere, 7, 1803-1818, https://doi.org/10.5194/tc-7-1803-2013, 2013.

Linke, C., Möhler, O., Veres, A., Mohácsi, Á., Bozóki, Z., Szabó, G., and Schnaiter, M.: Optical properties and mineralogical composition of different Saharan mineral dust samples: a laboratory study, Atmos. Chem. Phys., 6, 3315-3323, https://doi.org/10.5194/acp-6-3315-2006, 2006.

Maggi, V., Villa, S., Finizio, A., Delmonte, B., Casati, P., and Marino, F.: Variability of Anthropogenic and Natural Compounds in High Altitude-high Accumulation Alpine Glaciers, Hydrobiologia, 562, 43-56, https://doi.org/10.1007/s10750-0051804-y, 2006.

Mahowald, N., Albani, S., Kok, J. F., Engelstaeder, S., Scanza, R., Ward, D. S., and Flanner, M. G.: The size distribution of desert dust aerosols and its impact on the Earth system, Aeolian Res., 15, 53-71, https://doi.org/10.1016/j.aeolia.2013.09.002, 2013.

Mahowald, N. M., Kloster, S., Engelstaedter, S., Moore, J. K., Mukhopadhyay, S., McConnell, J. R., Albani, S., Doney, S. C., Bhattacharya, A., Curran, M. A. J., Flanner, M. G., Hoffman, F. M., Lawrence, D. M., Lindsay, K., Mayewski, P. A., Neff, J., Rothenberg, D., Thomas, E., Thornton, P. E., and Zender, C. S.: Observed 20th century desert dust variability: impact on climate and biogeochemistry, Atmos. Chem. Phys., 10, 10875-10893, https://doi.org/10.5194/acp-10-10875-2010, 2010.

Marx, S. K., Kamber, B. S., and McGowan, H. A.: Scavenging of atmospheric trace metal pollutants by mineral dusts: Inter-regional transport of Australian trace metal pollution to New Zealand, Atmos. Environ., 42, 2460-2478, https://doi.org/10.1016/J.ATMOSENV.2007.12.014, 2008.

Matt, F. N., Burkhart, J. F., and Pietikäinen, J.-P.: Modelling hydrologic impacts of light absorbing aerosol deposition on snow at the catchment scale, Hydrol. Earth Syst. Sci., 22, 179-201, https://doi.org/10.5194/hess-22-179-2018, 2018.

Meola, M., Lazzaro, A., and Zeyer, J.: Bacterial Composition and Survival on Sahara Dust Particles Transported to the European Alps, Front. Microbiol., 6, 1454, https://doi.org/10.3389/fmicb.2015.01454, 2015.

Migliavacca, M., Galvagno, M., Cremonese, E., Rossini, M., Meroni, M., Sonnentag, O., Cogliati, S., Manca, G., Diotri, F., Busetto, L., Cescatti, A., Colombo, R., Fava, F., Morra di Cella, U., Pari, E., Siniscalco, C., and Richardson, A. D.: Using digital repeat photography and eddy covariance data to model grassland phenology and photosynthetic $\mathrm{CO}_{2}$ uptake, Agric. For. Meteorol., 151, 1325-1337, https://doi.org/10.1016/j.agrformet.2011.05.012, 2011.

Moreno, T., Querol, X., Castillo, S., Alastuey, A., Cuevas, E., Herrmann, L., Mounkaila, M., Elvira, J., and Gibbons, W.: Geochemical variations in aeolian mineral particles from the Sahara-Sahel Dust Corridor, Chemosphere, 65, 261-270, https://doi.org/10.1016/J.CHEMOSPHERE.2006.02.052, 2006.

Nabat, P., Somot, S., Mallet, M., Michou, M., Sevault, F., Driouech, F., Meloni, D., di Sarra, A., Di Biagio, C., Formenti, P., Sicard, M., Léon, J.-F., and Bouin, M.-N.: Dust aerosol radiative effects during summer 2012 simulated with a coupled regional aerosol-atmosphere-ocean model over the Mediterranean, Atmos. Chem. Phys., 15, 3303-3326, https://doi.org/10.5194/acp15-3303-2015, 2015.

Neff, J. C., Ballantyne, A. P., Farmer, G. L., Mahowald, N. M., Conroy, J. L., Landry, C. C., Overpeck, J. T., Painter, T. H., Lawrence, C. R., and Reynolds, R. L.: Increasing eolian dust deposition in the western United States linked to human activity, Nat. Geosci., 1, 189-195, https://doi.org/10.1038/ngeo133, 2008.

Neves, N. R., Oliva, M. A., da Cruz Centeno, D., Costa, A. C., Ribas, R. F., and Pereira, E. G.: Photosynthesis and oxidative stress in the restinga plant species Eugenia uniflora $\mathrm{L}$. exposed to simulated acid rain and iron ore dust deposition: Potential use in environmental risk assessment, Sci. Total Environ., 407, 3740-3745, https://doi.org/10.1016/J.SCITOTENV.2009.02.035, 2009.

Oerlemans, J., Giesen, R. H., and Van Den Broeke, M. R.: Retreating alpine glaciers: increased melt rates due to accumulation of dust (Vadret da Morteratsch, Switzerland), J. Glaciol., 55, 729_ 736, https://doi.org/10.3189/002214309789470969, 2009.

Okin, G. S., Mahowald, N., Chadwick, O. A., and Artaxo, P.: Impact of desert dust on the biogeochemistry of phosphorus in terrestrial ecosystems, Global Planet. Change, 18, GB2005, https://doi.org/10.1029/2003GB002145, 2004.

Painter, T. H., Barrett, A. P., Landry, C. C., Neff, J. C., Cassidy, M. P., Lawrence, C. R., McBride, K. E., and Farmer, G. L.: Impact of disturbed desert soils on duration of mountain snow cover, Geophys. Res. Lett., 34, L12502, https://doi.org/10.1029/2007GL030284, 2007.

Painter, T. H., Skiles, S. M., Deems, J. S., Bryant, A. C., and Landry, C. C.: Dust radiative forcing in snow of the Upper Colorado River Basin: 1. A 6 year record of energy balance, radiation, and dust concentrations, Water Resour. Res., 48, W07521, https://doi.org/10.1029/2012WR011985, 2012a.

Painter, T. H., Bryant, A. C., and Skiles, S. M.: Radiative forcing by light absorbing impurities in snow from MODIS surface reflectance data, Geophys. Res. Lett., 39, L17502, https://doi.org/10.1029/2012GL052457, 2012b.

Painter, T. H., Seidel, F. C., Bryant, A. C., McKenzie Skiles, S., and Rittger, K.: Imaging spectroscopy of albedo and radiative forcing by light-absorbing impurities in mountain snow, J. Geophys. Res.-Atmos., 118, 9511-9523, https://doi.org/10.1002/jgrd.50520, 2013a.

Painter, T. H., Flanner, M. G., Kaser, G., Marzeion, B., VanCuren, R. A., and Abdalati, W.: End of the Little Ice Age in the Alps forced by industrial black carbon, P. Natl. Acad. Sci. USA, 110, 15216-15221, https://doi.org/10.1073/pnas.1302570110, 2013b.

Painter, T. H., Skiles, S. M., Deems, J. S., Brandt, W. T., and Dozier, J.: Variation in Rising Limb of Colorado River Snowmelt Runoff Hydrograph Controlled by Dust Radiative Forcing in Snow, Geophys. Res. Lett., 45, 797-808, https://doi.org/10.1002/2017GL075826, 2018.

Parajka, J., Haas, P., Kirnbauer, R., Jansa, J., and Blöschl, G.: Potential of time-lapse photography of snow for hydrological purposes 
at the small catchment scale, Hydrol. Process., 26, 3327-3337, https://doi.org/10.1002/hyp.8389, 2012.

Pérez, C., Haustein, K., Janjic, Z., Jorba, O., Huneeus, N., Baldasano, J. M., Black, T., Basart, S., Nickovic, S., Miller, R. L., Perlwitz, J. P., Schulz, M., and Thomson, M.: Atmospheric dust modeling from meso to global scales with the online NMMB/BSC-Dust model - Part 1: Model description, annual simulations and evaluation, Atmos. Chem. Phys., 11, 1300113027, https://doi.org/10.5194/acp-11-13001-2011, 2011.

Picard, G., Libois, Q., Arnaud, L., Verin, G., and Dumont, M.: Development and calibration of an automatic spectral albedometer to estimate near-surface snow SSA time series, The Cryosphere, 10, 1297-1316, https://doi.org/10.5194/tc-10-1297-2016, 2016.

Potenza, M. A. C., Albani, S., Delmonte, B., Villa, S., Sanvito, T., Paroli, B., Pullia, A., Baccolo, G., Mahowald, N., and Maggi, V.: Shape and size constraints on dust optical properties from the Dome C ice core, Antarctica, Sci. Rep., 6, 28162, https://doi.org/10.1038/srep28162, 2016.

Prodi, F. and Fea, G.: A case of transport and deposition of Saharan dust over the Italian Peninsula and southern Europe, J. Geophys. Res., 84, 6951, https://doi.org/10.1029/JC084iC11p06951, 1979.

Qiu, K., Xie, Y., Xu, D., and Pott, R.: Ecosystem functions including soil organic carbon, total nitrogen and available potassium are crucial for vegetation recovery, Sci. Rep., 8, 7607, https://doi.org/10.1038/s41598-018-25875-x, 2018.

Reynolds, R. L., Goldstein, H. L., Moskowitz, B. M., Bryant, A. C., Skiles, S. M., Kokaly, R. F., Flagg, C. B., Yauk, K., Berquó, T., Breit, G., Ketterer, M., Fernandez, D., Miller, M. E., and Painter, T. H.: Composition of dust deposited to snow cover in the Wasatch Range (Utah, USA): Controls on radiative properties of snow cover and comparison to some dust-source sediments, Aeolian Res., 15, 73-90, https://doi.org/10.1016/j.aeolia.2013.08.001, 2013.

Richardson, A. D., Jenkins, J. P., Braswell, B. H., Hollinger, D. Y., Ollinger, S. V., and Smith, M.-L.: Use of digital webcam images to track spring green-up in a deciduous broadleaf forest., Oecologia, 152, 323-334, https://doi.org/10.1007/s00442-006-0657-z, 2007.

Rizzolo, J. A., Barbosa, C. G. G., Borillo, G. C., Godoi, A. F. L., Souza, R. A. F., Andreoli, R. V., Manzi, A. O., Sá, M. O., Alves, E. G., Pöhlker, C., Angelis, I. H., Ditas, F., Saturno, J., MoranZuloaga, D., Rizzo, L. V., Rosário, N. E., Pauliquevis, T., Santos, R. M. N., Yamamoto, C. I., Andreae, M. O., Artaxo, P., Taylor, P. E., and Godoi, R. H. M.: Soluble iron nutrients in Saharan dust over the central Amazon rainforest, Atmos. Chem. Phys., 17, 2673-2687, https://doi.org/10.5194/acp-17-2673-2017, 2017.

Rudnick, R. L. and Gao, S.: Composition of the Continental Crust, in: Treatise on Geochemistry, vol. 3, 1-64, available at: https://www.sciencedirect.com/science/article/pii/ B9780080959757003016 (last access: 2 April 2019), Elsevier, 2003.

Ruth, U., Barbante, C., Bigler, M., Delmonte, B., Fischer, H., Gabrielli, P., Gaspari, V., Kaufmann, P., Lambert, F., Maggi, V., Marino, F., Petit, J.-R., Udisti, R., Wagenbach, D., Wegner, A., and Wolff, E. W.: Proxies and Measurement Techniques for Mineral Dust in Antarctic Ice Cores, Environ. Sci. Technol., 42, 5675-5681, https://doi.org/10.1021/es703078z, 2008.
Sardans, J. and Peñuelas, J.: Potassium: a neglected nutrient in global change, Glob. Ecol. Biogeogr., 24, 261-275, https://doi.org/10.1111/geb.12259, 2015.

Schaffner, U., Alewell, C., Eschen, R., Matthies, D., Spiegelberger, T., and Hegg, O.: Calcium Induces Long-Term Legacy Effects in a Subalpine Ecosystem, edited by: Kytöviita, M.-M., PLoS One, 7, e51818, https://doi.org/10.1371/journal.pone.0051818, 2012.

Schwikowski, M., Seibert, P., Baltensperger, U., and Gaggeler, H. W.: A study of an outstanding Saharan dust event at the high-alpine site Jungfraujoch, Switzerland, Atmos. Environ., 29, 1829-1842, https://doi.org/10.1016/1352-2310(95)00060-C, 1995.

Sen, I. S. and Peucker-Ehrenbrink, B.: Anthropogenic Disturbance of Element Cycles at the Earth's Surface, Environ. Sci. Technol., 46, 8601-8609, https://doi.org/10.1021/es301261x, 2012.

Sheppard, P. R., Toepfer, P., Schumacher, E., Rhodes, K., Ridenour, G., and Witten, M. L.: Morphological and Chemical Characteristics of Airborne Tungsten Particles of Fallon, Nevada, Microsc. Microanal., 13, 296-303, https://doi.org/10.1017/S1431927607070237, 2007.

Sigl, M., Abram, N. J., Gabrieli, J., Jenk, T. M., Osmont, D., and Schwikowski, M.: 19th century glacier retreat in the Alps preceded the emergence of industrial black carbon deposition on high-alpine glaciers, The Cryosphere, 12, 3311-3331, https://doi.org/10.5194/tc-12-3311-2018, 2018.

Skiles, S. M., Painter, T. H., Deems, J. S., Bryant, A. C., and Landry, C. C.: Dust radiative forcing in snow of the Upper Colorado River Basin: 2. Interannual variability in radiative forcing and snowmelt rates, Water Resour. Res., 48, W07522, https://doi.org/10.1029/2012WR011986, 2012.

Skiles, S. M., Flanner, M., Cook, J. M., Dumont, M., and Painter, T. H.: Radiative forcing by light-absorbing particles in snow, Nat. Clim. Change, 8, 964-971, https://doi.org/10.1038/s41558-0180296-5, 2018.

Sodemann, H., Palmer, A. S., Schwierz, C., Schwikowski, M., and Wernli, H.: The transport history of two Saharan dust events archived in an Alpine ice core, Atmos. Chem. Phys., 6, 667-688, https://doi.org/10.5194/acp-6-667-2006, 2006.

Steltzer, H., Landry, C., Painter, T. H., Anderson, J., and Ayres, E.: Biological consequences of earlier snowmelt from desert dust deposition in alpine landscapes, P. Natl. Acad. Sci. USA, 106, 11629-11634, https://doi.org/10.1073/pnas.0900758106, 2009.

Sun, S.-S. and McDonough, W. F.: Chemical and isotopic systematics of oceanic basalts: implications for mantle composition and processes, Geol. Soc. London, Spec. Publ., 42, 313-345, https://doi.org/10.1144/GSL.SP.1989.042.01.19, 1989.

Tegen, I. and Lacis, A. A.: Modeling of particle size distribution and its influence on the radiative properties of mineral dust aerosol, J. Geophys. Res.-Atmos., 101, 19237-19244, https://doi.org/10.1029/95JD03610, 1996.

Tegen, I., Lacis, A. A., and Fung, I.: The influence on climate forcing of mineral aerosols from disturbed soils, Nature, 380, 419422, https://doi.org/10.1038/380419a0, 1996.

Telloli, C., Chicca, M., Pepi, S., and Vaccaro, C.: Saharan dust particles in snow samples of Alps and Apennines during an exceptional event of transboundary air pollution, Environ. Monit. Assess., 190, 37, https://doi.org/10.1007/s10661-017-6412-6, 2018.

Thackeray, S. J., Henrys, P. A., Hemming, D., Bell, J. R., Botham, M. S., Burthe, S., Helaouet, P., Johns, D. G., Jones, I. D., 
Leech, D. I., Mackay, E. B., Massimino, D., Atkinson, S., Bacon, P. J., Brereton, T. M., Carvalho, L., Clutton-Brock, T. H., Duck, C., Edwards, M., Elliott, J. M., Hall, S. J. G., Harrington, R., Pearce-Higgins, J. W., Høye, T. T., Kruuk, L. E. B., Pemberton, J. M., Sparks, T. H., Thompson, P. M., White, I., Winfield, I. J., and Wanless, S.: Phenological sensitivity to climate across taxa and trophic levels, Nature, 535, 241-245, https://doi.org/10.1038/nature18608, 2016.

Thevenon, F., Anselmetti, F. S., Bernasconi, S. M., and Schwikowski, M.: Mineral dust and elemental black carbon records from an Alpine ice core (Colle Gnifetti glacier) over the last millennium, J. Geophys. Res.-Atmos., 114, D17102, https://doi.org/10.1029/2008JD011490, 2009.

Thornton, P. E., Doney, S. C., Lindsay, K., Moore, J. K., Mahowald, N., Randerson, J. T., Fung, I., Lamarque, J.-F., Feddema, J. J., and Lee, Y.-H.: Carbon-nitrogen interactions regulate climate-carbon cycle feedbacks: results from an atmosphereocean general circulation model, Biogeosciences, 6, 2099-2120, https://doi.org/10.5194/bg-6-2099-2009, 2009.

Tuzet, F., Dumont, M., Lafaysse, M., Picard, G., Arnaud, L., Voisin, D., Lejeune, Y., Charrois, L., Nabat, P., and Morin, S.: A multilayer physically based snowpack model simulating direct and indirect radiative impacts of light-absorbing impurities in snow, The Cryosphere, 11, 2633-2653, https://doi.org/10.5194/tc-112633-2017, 2017.

Vaughan, D. G., Comiso, J. C., Allison, I., Carrasco, J., Kaser, G., Kwok, R., Mote, P., Murray, T., Paul, F., Ren, J., Rignot, E., Solomina, O., Steffen, K., and Zhang, T.: Observations: Cryosphere, in: Climate Change 2013: The Physical Science Basis, Contribution of Working Group I to the Fifth Assessment Report of the Intergovernmental Panel on Climate Change, Cambridge University Press, Cambridge, United Kingdom and New York, NY, USA, available at: https://www.ipcc.ch/site/assets/ uploads/2018/02/WG1AR5_Chapter04_FINAL.pdf (last access: 2 April 2019), 2013.

Verfaillie, D., Lafaysse, M., Déqué, M., Eckert, N., Lejeune, Y., and Morin, S.: Multi-component ensembles of future meteorological and natural snow conditions for $1500 \mathrm{~m}$ altitude in the Chartreuse mountain range, Northern French Alps, The Cryosphere, 12, 1249-1271, https://doi.org/10.5194/tc-12-1249-2018, 2018.
Vionnet, V., Brun, E., Morin, S., Boone, A., Faroux, S., Le Moigne, P., Martin, E., and Willemet, J.-M.: The detailed snowpack scheme Crocus and its implementation in SURFEX v7.2, Geosci. Model Dev., 5, 773-791, https://doi.org/10.5194/gmd-5773-2012, 2012.

Vlastelic, I., Suchorski, K., Sellegri, K., Colomb, A., Nauret, F., Bouvier, L., and Piro, J.-L.: The high field strength element budget of atmospheric aerosols (puy de Dôme, France), Geochim. Cosmochim. Acta, 167, 253-268, https://doi.org/10.1016/J.GCA.2015.07.006, 2015.

Wang, M., Xu, B., Cao, J., Tie, X., Wang, H., Zhang, R., Qian, Y., Rasch, P. J., Zhao, S., Wu, G., Zhao, H., Joswiak, D. R., Li, J., and Xie, Y.: Carbonaceous aerosols recorded in a southeastern Tibetan glacier: analysis of temporal variations and model estimates of sources and radiative forcing, Atmos. Chem. Phys., 15, 1191-1204, https://doi.org/10.5194/acp-15-1191-2015, 2015.

Warren, S. G. and Wiscombe, W. J.: A Model for the Spectral Albedo of Snow, II: Snow Containing Atmospheric Aerosols, J. Atmos. Sci., 37, 2734-2745, https://doi.org/10.1175/15200469(1980)037<2734:AMFTSA>2.0.CO;2, 1980.

Weil, T., De Filippo, C., Albanese, D., Donati, C., Pindo, M., Pavarini, L., Carotenuto, F., Pasqui, M., Poto, L., Gabrieli, J., Barbante, C., Sattler, B., Cavalieri, D., and Miglietta, F.: Legal immigrants: invasion of alien microbial communities during winter occurring desert dust storms, Microbiome, 5, 32, https://doi.org/10.1186/s40168-017-0249-7, 2017.

Wittmann, M., Groot Zwaaftink, C. D., Steffensen Schmidt, L., Guðmundsson, S., Pálsson, F., Arnalds, O., Björnsson, H., Thorsteinsson, T., and Stohl, A.: Impact of dust deposition on the albedo of Vatnajökull ice cap, Iceland, The Cryosphere, 11, 741-754, https://doi.org/10.5194/tc-11-741-2017, 2017.

Yu, H., Chin, M., Yuan, T., Bian, H., Remer, L. A., Prospero, J. M., Omar, A., Winker, D., Yang, Y., Zhang, Y., Zhang, Z., and Zhao, C.: The fertilizing role of African dust in the Amazon rainforest: A first multiyear assessment based on data from Cloud-Aerosol Lidar and Infrared Pathfinder Satellite Observations, Geophys. Res. Lett., 42, 1984-1991, https://doi.org/10.1002/2015GL063040, 2015. 